\title{
Article \\ Predicting Snowmelt Runoff at the Source of the Mountainous Euphrates River Basin in Turkey for Water Supply and Flood Control Issues Using HEC-HMS Modeling
}

\author{
Selim Şengül *(i) and Muhammet Nuri İspirli (i) \\ Department of Civil Engineering, Faculty of Engineering, Atatürk University, Erzurum 25100, Turkey; \\ m.nurii@hotmail.com \\ * Correspondence: ssengul@atauni.edu.tr; Tel.: +90-442-2314569
}

check for

updates

Citation: Şengül, S.; İspirli, M.N.

Predicting Snowmelt Runoff at the Source of the Mountainous

Euphrates River Basin in Turkey for Water Supply and Flood Control Issues Using HEC-HMS Modeling. Water 2022, 14, 284. https://doi.org/ $10.3390 / w 14030284$

Academic Editors: Dengfeng Liu, Hui Liu and Xianmeng Meng

Received: 15 December 2021

Accepted: 15 January 2022

Published: 18 January 2022

Publisher's Note: MDPI stays neutral with regard to jurisdictional claims in published maps and institutional affiliations.

Copyright: (C) 2022 by the authors. Licensee MDPI, Basel, Switzerland. This article is an open access article distributed under the terms and conditions of the Creative Commons Attribution (CC BY) license (https:// creativecommons.org/licenses/by/ $4.0 /)$.

\begin{abstract}
Predicting the runoff from snowpack accumulated in mountainous basins during the melting periods is very important in terms of assessing issues such as water supply and flood control. In this study, the Hydrological Engineering Center-Hydrological Modeling System (HEC-HMS) was used to simulate snowmelt runoff in the Kırkgöze-Çipak Basin that has a complex topography where altitude differences range from $1823 \mathrm{~m}$ to $3140 \mathrm{~m}$ above the sea level. The Kırkgöze-Çipak Basin, located in eastern Turkey, is a basin where snowfall is highly effective during the cold season. There are three automatic meteorology and snow observation stations and three stream gauge stations in the basin, which are operated especially for the calibration and validation of hydrological parameters at different altitudes and exposures. In this study, the parameters affecting snow accumulationmelting and runoff were investigated using the simulations on an hourly basis carried out over a three-year period for temporal and spatial distribution at the basin scale. Different from previous studies focusing on the rate of snowmelt, the temperature index method, which is calculated with physically-based parameters $\left(R^{2}=0.77 \sim 0.99\right)$, was integrated into the runoff simulations $\left(R^{2}=0.84\right)$ in the basin. The snowmelt-dominated basin is considered to be the source of the headwaters of the Euphrates River.
\end{abstract}

Keywords: snowmelt; hydrologic modeling; ATIMR; HEC-HMS; Euphrates River; Kırkgöze-Çipak Basin

\section{Introduction}

Water is the source of life and is probably the most valuable natural asset in the Middle East. Within this perspective, the history of water management is nothing less than the history of humankind. From the inception of our species, coping with the availability-or unavailability - of water resources has been an essential element of human beings' strategies for survival and wellbeing [1]. The two largest rivers in Western Asia, the Euphrates and Tigris, flow in Turkey, Syria, Iran, Iraq, and Saudi Arabia. The Euphrates and Tigris basins are fed predominantly by snow precipitation. Approximately two-thirds of this occurs in winter, and the snow may remain for half a year [2]. Consequently, where water supplies are under stress, such as the semiarid regions of the Mediterranean basins, the activity of snowmelt-derived streamflows are extremely important [3].

The mountain snowfall acts as a natural reservoir for storing precipitation during the cold season, and during the spring months it melts and flows to the rivers. Understanding when the snow melts and the resulting streamflow occurs is essential to be able to effectively manage water resources. Analyses of how the amount and timing of these hydrological quantities vary are crucial to the water supply systems in mountain regions [4]. It is particularly important in the Euphrates and Tigris basins where there are large reservoirs. Results obtained from the hydrological modeling system algorithms of the snowmeltdominated mountainous Kırkgöze-Çipak Basin improve the accuracy of water resource simulations and help in the planning and operation of the Euphrates River flows. 
To date, researchers have introduced a wide variety of modeling frameworks to model the hydrological process [5-7]. In general, these modeling frameworks can be divided into three main groups: conceptual, physically-based, and machine learning models. Conceptual and physically-based models can be used for research purposes to improve knowledge and understanding of the hydrological processes that govern the real-world system. On the other hand, machine learning models create a direct mapping between precipitation and runoff variables and infer their relationships based on historical observations with machine learning algorithms without prior knowledge of internal hydrological processes [8]. Hydrological models are also developed and used for simulation and forecasting tools that allow decision-makers to make the most effective decisions for planning and operations, taking into account the interactions of the physical, ecological, economic, and social aspects of the real-world system. In addition, real-time flood forecasting and warning, flood frequency forecasting, flood route and overflow forecasting, climate and land-use change, and impact assessments of integrated basin management are examples of other applications in which the hydrological models are used [7,9].

In regions where most of the precipitation falls as snow during the winter months as the altitude increases, the snowmelt component of the hydrological models is vital for water resources management [10]. From a hydrological perspective, two main methods are generally used to simulate snowmelt: energy budget and temperature index methods. The energy budget method needs detailed observation data and a wide range of model parameters. The distribution of meteorological and hydrological stations in mountain basins is often limited, making it difficult to obtain and process the detailed information required for model study [11]. In contrast, the temperature index method uses air temperature as the only index of energy exchange at the snow surface [12]. The latter approach is commonly used in real-time hydrological forecasts. Examples of numerical models using the temperature index method include the National Weather Service River Forecast System model (1995), Streamflow Synthesis and Reservoir Regulation (SSARR) model, Hydrologic Engineering Center (HEC-1) model, Snowmelt Runoff Model for Windows (WinSRM), Cold Regions Hydrological Model (CRHM), Mesoscale Hydrologic Model (mHM), and the HEC-Hydrologic Modeling System (HEC-HMS) [13-17]. HEC-HMS model is a flexible hydrological model with particular physical significance designed to simulate a comprehensive range of hydrological processes coupled with a very sophisticated graphical user interface [18]. Modified melting rates have been used by many studies, using the hypothetical ATIMR (antecedent temperature index-melt rate) function used in the snowmelt module of HEC-HMS during calibration [19-22]; however, a commonly observed shortcoming in published literature is that no particular data is used to directly estimate the ATIMR curve. Therefore, its estimation and application to a mountainous basin with flow sources of complex composition is noteworthy here [23]. The method provided by Fazel et al. (2014) for one snowmelt period at distinct station locations was subsequently developed and applied by Şengül and İspirli (2021) to create ATIMR curves specific to the Kırkgöze-Çipak Basin using hourly temperatures and snow-water equivalent (SWE) data using error analysis methods recommended by Bombardelli and García (2003) obtained from the three meteorology and snow observation stations [24-26]. Their results showed that the application of the ATIMR function using the observed data significantly improves the snowpack simulations, and it is quite useful for runoff simulations.

Although Turkey is a peninsula, it has a geography with an average altitude of over 1100 meters. Snowmelt runoff in the mountainous eastern part of Turkey is of great importance as it constitutes 60 to $70 \%$ in volume of the total yearly runoff during the spring and the early summer months [27]. Most of the annual water volumes in the dam reservoirs built in this region come from the precipitation in the winter months, snowmelt, and the rain falling on the snow cover in the spring. For this reason, conducting hydrological model studies based on snowmelt in the Eastern Anatolia Region of Turkey, where the snow potential is quite high, are of great importance both on a regional, national, and international scale in terms of the planning and economic management of water resources $[25,27,28]$. 
Advances in Geographic Information Systems and availability of geospatial databases have paved the way for estimation of several hydroclimatic variables. Reducing the uncertainties in these estimations made at various scales provides a better description of hydrological regimes [29,30].

In this study, which uses these advances in the availability of geospatial data, a continuous hydrological modeling approach is discussed by incorporating the soil moisture account (SMA) algorithm [31] with the snow accumulation and melting algorithm. The Hydrologic Engineering Center's Hydrologic Modeling System [18] was applied to the Kırkgöze-Çipak basin (Figure 1), considering the characteristic behaviors of point and areabased snow-water equivalent simulations by using the most sensitive ATIMR functions calculated on a physical basis [25], and the precipitation distribution algorithms embedded in the model were modified for depicting the actual watershed conditions. The development stages of the model, the determination of the parameters, and the calibration process are explained, and the model results are discussed.

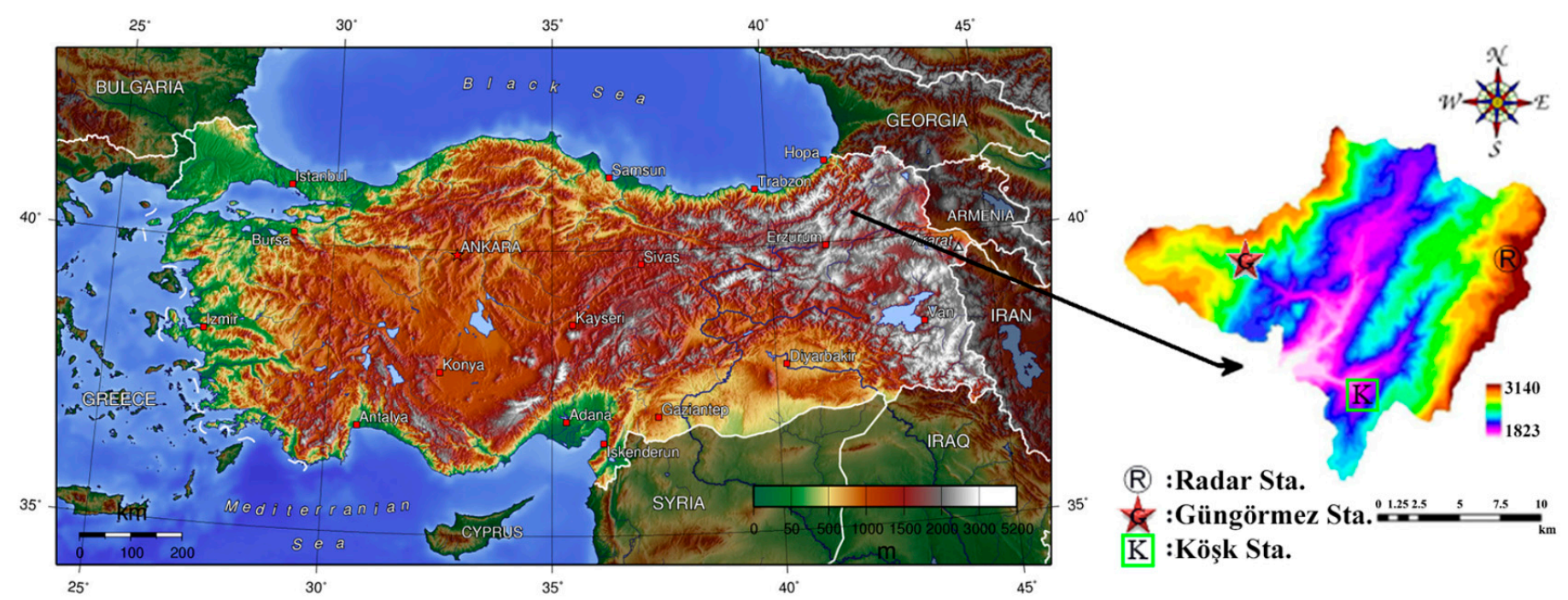

Figure 1. Study area and station locations.

\section{Materials and Methods}

\subsection{Area of Study}

This study chose the Kırkgöze-Çipak Basin, located near the source of the Karasu Basin (Upper Euphrates Basin)—which is itself a sub-basin of the Euphrates River-as the test area for this research. With an area of $242 \mathrm{~km}^{2}$ and altitude ranging from 1823 to $3140 \mathrm{~m}$, the Kırkgöze-Çipak Basin is shown on the digital elevation model (DEM) in Figure 1. The median elevation of the basin is $2325 \mathrm{~m}$, while the mean total basin slope is 15.3 degrees. The geography comprises a rugged mountainous area with the main area being pasture and bare land. The characteristic climatological conditions are those of a cold, dry, and windy region. The region is covered by snow at least 150 days per year, and a significant part of the precipitation falls in the form of snow. The catchment area is not affected by urbanization or by reservoir regulation. Although the basin can be considered small in terms of scale, it has a large elevation difference that makes it possible to conduct snow modeling of major basins such as the Euphrates Basin. Previous snow studies in the area have shown how important snow dynamics and snow modeling are for this region [2,10,27,32-41]. The study area is located within the city center limits of Erzurum in Turkey, which is located at the intersection of Turkey's three major basins: the Çoruh, Aras, and Euphrates basins, and the snowmelt of the mountains in this region is the main source of water for these basins [3,42]. Therefore, the input parameters of the snowmelt model applied in this study will also be a good starting point for hydrological modeling studies of other mainstream resources in the vicinity. 
The Kırkgöze-Çipak Basin includes a few state-built stations in its vicinity; however, these stations cannot provide enough information to effectively represent the pertinent spatial and temporal quality of the snowmelt-dominated basin. To compensate for this, three different automatic meteorology and snow observation stations that had been established in the Kırkgöze-Çipak Basin at the villages of Güngörmez and Köşk, inside the grounds of a military radar location under a prior project numbered TÜBİTAK 106Y293, were developed over time. Station information is provided in Table 1 for each of the locations that are shown in Figure 1. This allowed climate data from stations in a mountainous basin with high snow potential to be collected in real time and of sufficient quality $[35,36]$.

Table 1. Parameters of the meteorology stations.

\begin{tabular}{cccccc}
\hline $\begin{array}{c}\text { Automatic Meteorology } \\
\text { and Snow } \\
\text { Observation Station }\end{array}$ & $\begin{array}{c}\text { Altitude } \\
(\mathbf{m})\end{array}$ & Aspect & Land Use & $\begin{array}{c}\text { Average Slope of } \\
\text { Land Close to the } \\
\text { Station (Degrees) }\end{array}$ & Simulation Time Interval \\
\hline KÖŞK & 2019 & Northwest & Dry Farming & 9.90 & $10 / 22 / 2008-9 / 30 / 2011$ \\
GÜNGÖRMEZ & 2454 & Southeast & Transition Area & 24.10 & $10 / 22 / 2008-9 / 30 / 2011$ \\
RADAR & 2891 & Northwest & Transition Area & 12.06 & $10 / 22 / 2008-9 / 30 / 2011$ \\
\hline
\end{tabular}

The upper levels of the study area are surrounded by basalts. These structures were formed as a result of numerous volcanic activities, so they show a complex structure that includes other volcanic rocks. The accumulated groundwater either discharges as small seasonal springs or is channeled to the adjacent formation comprising tuff and agglomerate (Figure 2). Tuff and agglomerate are common under basalts in this region. They were formed as a result of the cementation of angular pebbles of different size and blocks containing basalt, andesite, and tuff with fine-grained volcanic rocks.

The agglomerates, which are faulted and fractured in several directions, carry a small amount of groundwater in the fracture zones. In the region, tuff and agglomerate-inclusive claystone and marl layers are located due to the unconformity under the agglomerate. Many small seasonal springs are observed at the boundary of the clay and marl layer, which has a more impermeable structure than the formations above it [43]. 


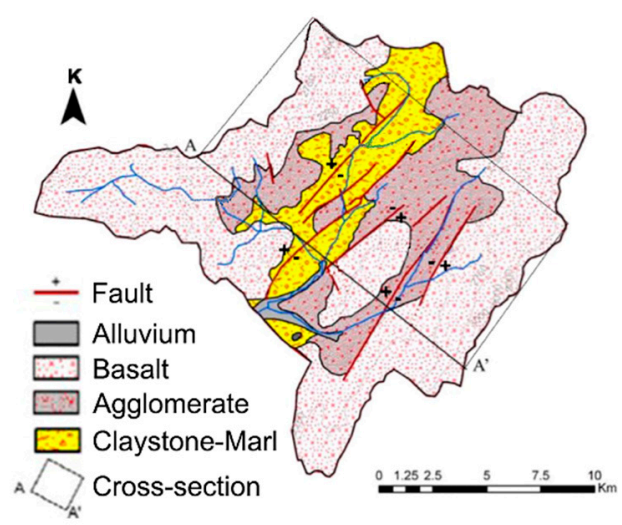

(a)

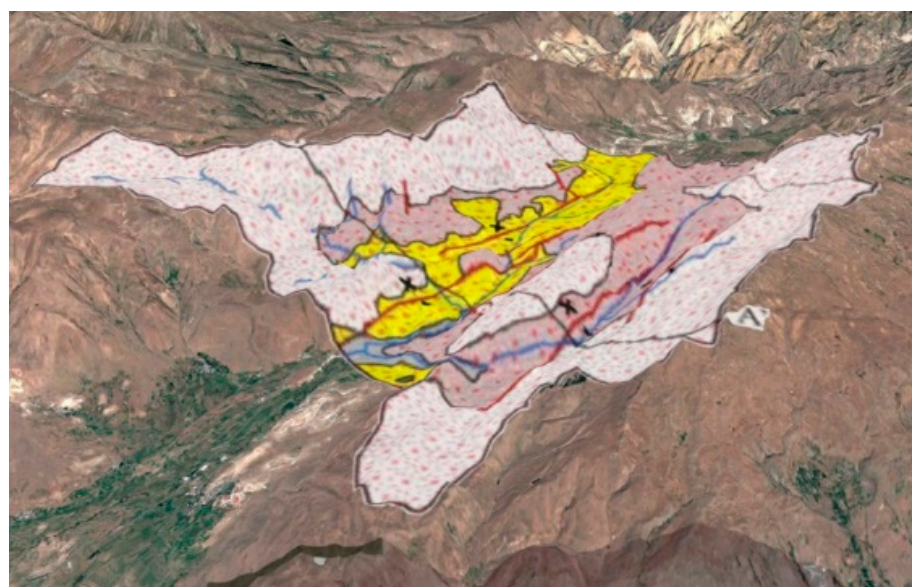

(b)

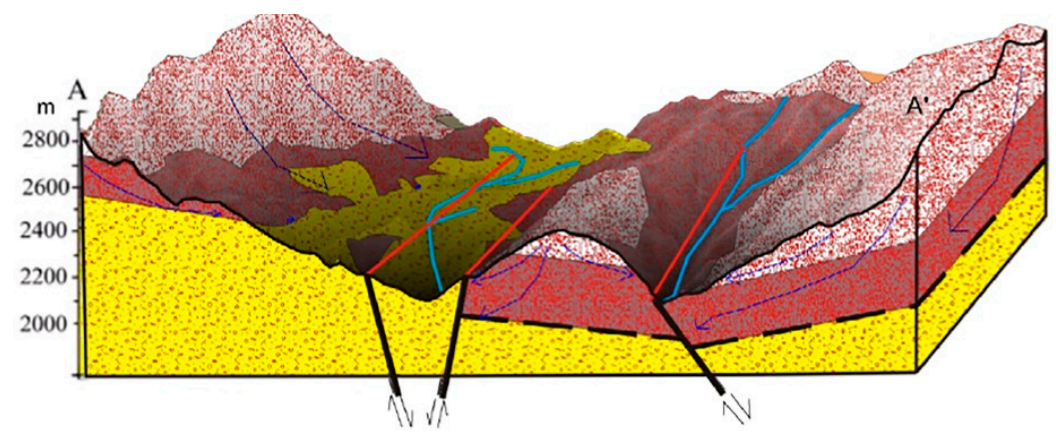

(c)

Figure 2. (a) Geological map. (b) Land survey. (c) A-A' geological cross-section of Kırkgöze-Çipak basin [44].

\subsection{Hydrological Model}

The Hydrologic Engineering Center's Hydrologic Modeling System (HEC-HMS) is a hydrological model developed to simulate the precipitation-runoff processes of dendritic drainage basin systems [18]. The model is designed for both continuous and event-based hydrological modeling and offers several different options for modeling the various components of the hydrological cycle. In event-based modeling, storm precipitation is simulated during the simulation time interval ranging from a few hours to several days, depending on the basin size [45]. In continuous modeling, a continuous historical record of hydrological events, including dry and wet periods over several years, is simulated [46]. The main difference is that evapotranspiration and groundwater seepage can be neglected in eventbased modeling, while they cannot be ignored in continuous simulation [47]. HEC-HMS can conduct hydrological simulation over a wide range with various simple modules to represent different components of the hydrological cycle. The selection of the appropriate model for each component depends on the experience of the modeler, the purpose of the modeling, and the usability of the input data [48].

The HEC-HMS modeling system has three main components: the basin model in which the topographic and physical characteristics of the basin are determined, the meteorological model in which the meteorological data are processed, and the control manager.

\subsection{Basin Model}

The HEC-HMS basin model (Figure 3) simulates the process of the water falling to Earth by precipitation from the canopy to become groundwater, excluding bottom percolation. HEC-HMS uses the soil moisture accounting (SMA) [31] algorithm to simulate the movement of water in soil under continuous simulations. This algorithm takes precipitation and evapotranspiration as inputs and computes surface runoff, groundwater runoff, 
evapotranspiration, and losses from bottom percolation (Figure 4; see USACE (2016) for further detail). The Clark Unit Hydrograph was chosen for the transformation method (or hydrograph simulation) and the monthly constant baseflow method was chosen for the baseflow calculation $[49,50]$. Initial parameters for the Clark method were obtained using the Kerby equation $\left(\mathrm{Tc}=\mathrm{G}\left(\mathrm{L}^{*} \mathrm{r} / \mathrm{S} 0.5\right) 0.467\right)$. The physical parameters of the sub-basins at the exit of the three selected meteorological stations (for example, river length, drainage area, slope, etc.) were computed with Geographic Information Systems (GIS) by using the digital elevation model (DEM) obtained from the $10 \mathrm{~m}$ contour maps (Table 2). The initial values for the baseflow were taken as the current river flows because the beginning of the simulation was in the dry period, and they were distributed on the basis of the average area-based distribution in the sub-basins.

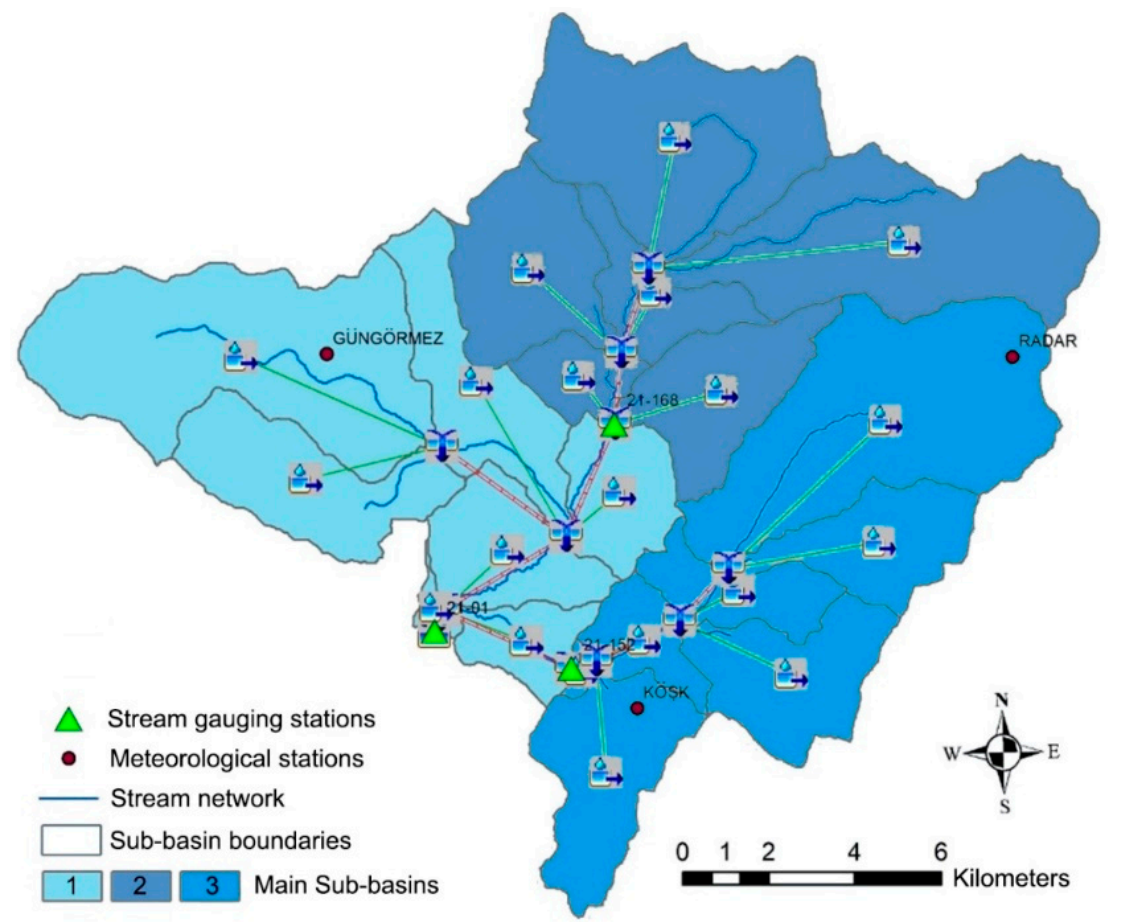

Figure 3. Conceptual model of the Kırkgöze-Çipak Basin in HMS, showing junctions, reaches, flow direction, and sub-basins.

The basin model includes many parameters used for baseflow, hydrograph simulation, and SMA. For the estimation of these parameters in previous studies [10,45,51-53], it was found appropriate to use geodatabases, reducing the number of free parameters by starting the simulation during periods when initial conditions are easier to predict (i.e., the start of the water year), and use empirical equations or reliable sources. A combination of these methods was used in this study. As there was no map from which soil texture information of the study area could be obtained, the initial values of SMA were obtained from previous studies and then calibrated to match the observed streamflow. Canopy maximum retention and soil surface deposition were estimated by vegetation type and percentage of land slope, respectively $[54,55]$. The rate and amount of seepage in the soil profile and groundwater were estimated based on hydraulic conductivity [52]. Active soil depth was assumed to be $60 \mathrm{~cm}$, considering the land cover. Fleming and Neary (2004) predicted HEC-HMS groundwater storage (groundwater 1 and groundwater 2), and seepage parameters [18] were based on recession analysis. These estimates from published literature were taken as initial values and they were calibrated during the simulations.

\subsection{Meteorological Model}

The Kırkgöze-Çipak basin is divided into a few sub-basins, as shown in Figure 3. The data obtained from three automatic meteorology and snow observation stations in 
the basin at altitudes of 2019 m (Köşk), 2454 m (Güngörmez), and $2891 \mathrm{~m}$ (Radar) were used for the meteorological data required for the different parameter methods selected in the basin and for the meteorological model simulating the precipitation-runoff process. These stations provided time series of the maximum wind speed (m/s), wind direction, average air temperature $\left({ }^{\circ} \mathrm{C}\right)$, average humidity $(\% \mathrm{rh})$, air pressure (mbar), average soil temperature $\left({ }^{\circ} \mathrm{C}\right)$, solar radiation $\left(\mathrm{W} / \mathrm{m}^{2}\right)$, average albedo, precipitation $(\mathrm{mm})$, snow height $(\mathrm{cm})$, snow density $\left(\mathrm{gr} / \mathrm{cm}^{3}\right)$, and snow-water equivalent $(\mathrm{cm})$ parameters over $15 \mathrm{~min}$ periods. References $[35,36]$ showed that the climate data from the stations in the basin was sufficient, of good quality, and could be collected in real time. Measurements from the years 2008 to 2011 obtained from the Köşk, Güngörmez, and Radar meteorology stations were used for the hydrological simulations to be conducted with HEC-HMS.

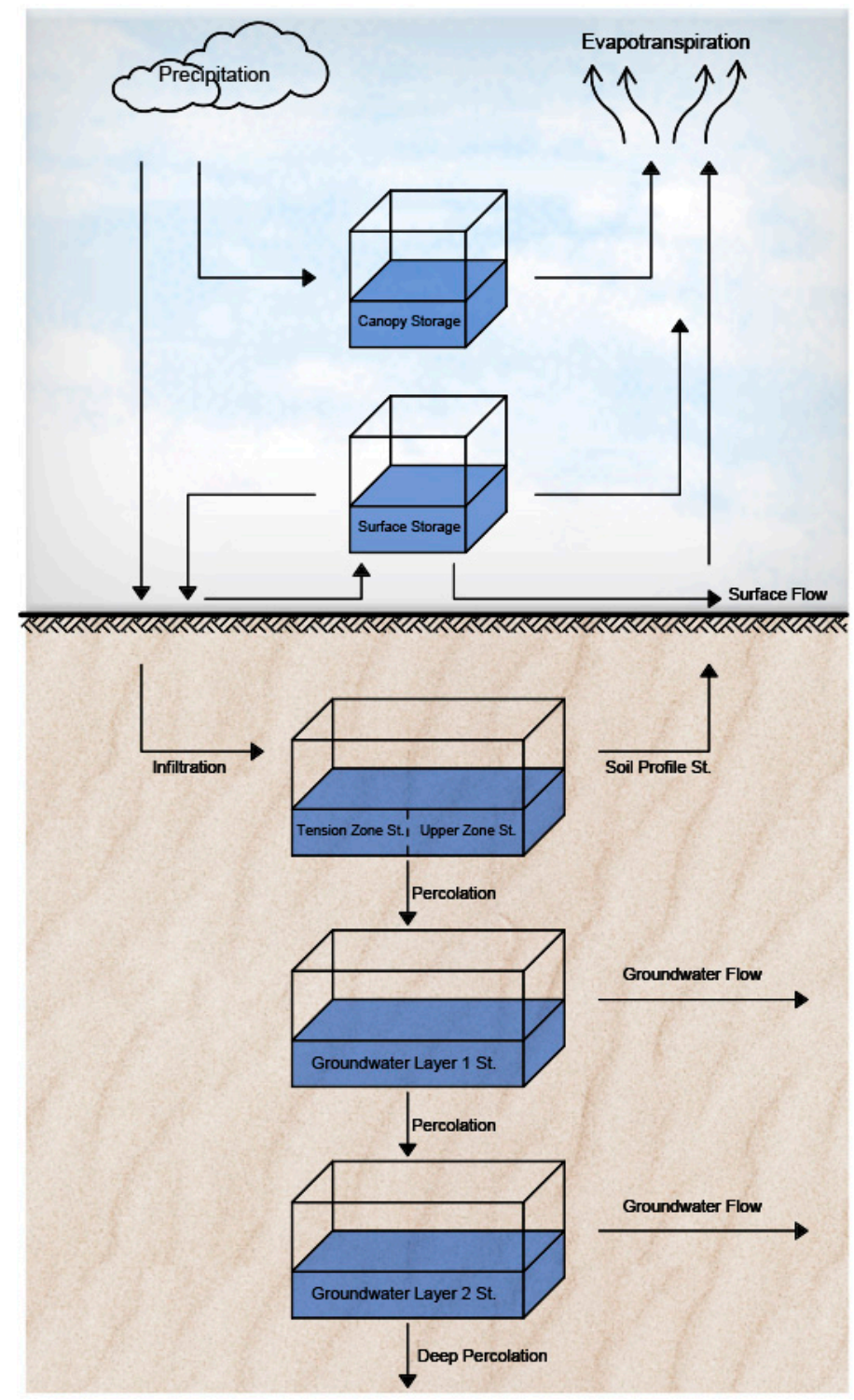

Figure 4. Schematic of basin model in HEC-HMS and its principal components. 
Table 2. Physical properties of the main sub-basins.

\begin{tabular}{cccc}
\hline & MS1 & MS2 & MS3 \\
\hline Basin Slope (\%) & 0.173 & 0.167 & 0.215 \\
Elevation (m) & 2125.02 & 2175.37 & 2204.53 \\
River Length (m) & $21,917.56$ & $12,094.25$ & $11,208.97$ \\
Area $\left(\mathrm{km}^{2}\right)$ & 91.53 & 75.50 & 74.51 \\
\hline
\end{tabular}

\subsection{Precipitation Model}

A variety of different statistical techniques to distribute point observations over complex topography is given in published literature [56-64]. Although these studies improved high-resolution grid-type climate data estimations, uncertainties remained. In particular, it is more difficult to estimate the spatial distribution and the intensity of precipitation compared to other variables such as temperature, due to the regional, seasonal, and topographic characteristics [65]. The Kırkgöze-Çipak basin study area has a very large altitude range and other variable aspects, even though it is small in terms of scale. As a result of observations in the basin over a long time, it was determined that some convective precipitations took place independently from each other as in the northern aspects with quite high land altitudes where the Radar station is located and in the southern aspects where the Güngörmez station is located. Therefore, while snowmelt runoff simulations are performed throughout the basin, the emphasis is on how the precipitation is distributed regionally rather than how the precipitation may be distributed in the basin. The HEC-HMS program offers grid-based and polygonal-based solution alternatives to determine the precipitation distribution over the basin. This study was carried out on a polygonal basis, and the gage weights method was chosen for modeling the precipitation processes. The gage weights method is based on the Thiessen polygon method. The Thiessen polygon method, which is usually recommended for use in vast areas, does not distribute precipitation with respect to topographical effects and precipitation characteristics; instead, it performs it only over polygonal areas determined by the positions of the stations [66]. Therefore, the gage weights method used in HEC-HMS was modified for the study basin, which is heterogeneous in terms of altitude and exposure. While developing this polygonal area-based algorithm, in addition to the general behavior that is dependent on the topography of the region-the barrier effect (Figure 5, 4th elevation zone), the measurement data at the stream gauge stations and the ambient temperature, humidity, atmospheric pressure, rate of increase in cloudiness (observed), albedo, wind speed, and SWE values were all simultaneously examined. The area-based distribution of precipitation was simulated by six different zonal polygons shown in Figure 5.

In basins where there is a large altitude range, the use of data obtained from stations representing low levels may cause the precipitation input calculated for the entire basin to be lower than the actual value. It is recommended to extrapolate precipitation data to average hypsometric elevations for zones with elevation gradients [67], so that the point-based input values used in the modeling procedure can better represent a specific area. It is important for the precipitation data to align with other meteorological data with respect to time, so that the model can perform the necessary iterations accurately and reliably. For this reason, while making the area-based distribution of meteorological data, a general grouping based on altitude and exposure, taking into account station locations, was deemed appropriate so that simultaneous atmospheric homogeneity could be assured. For this reason, the meteorological variables in altitude zones 1 and 2 were based on the Güngörmez station, the meteorological variables in altitude zones 3 and 4 were based on the Kössk station, and the meteorological variables in altitude zones 5 and 6 were based on the Radar station variables (Figure 5). In Table 3, the hypsometric elevations for each zone and the altitudes of the meteorological stations in these zones are given. 


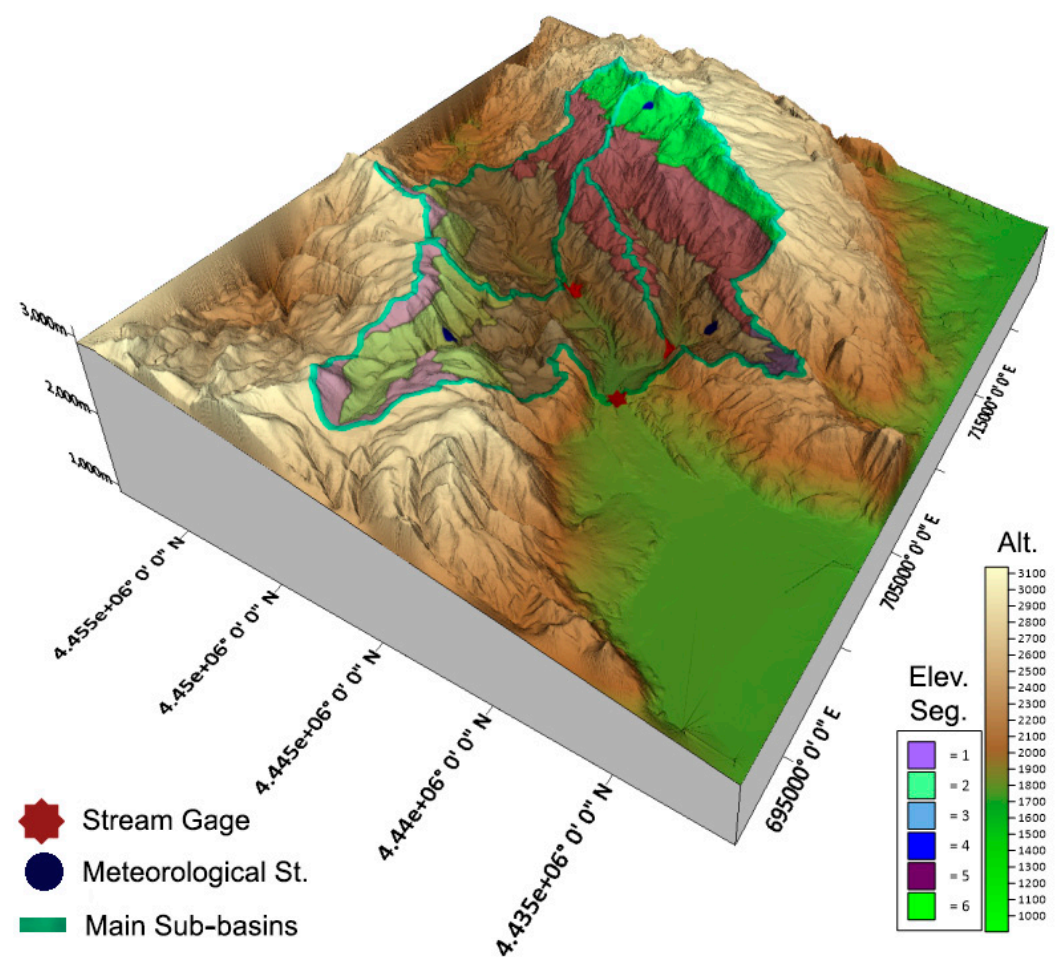

(a)

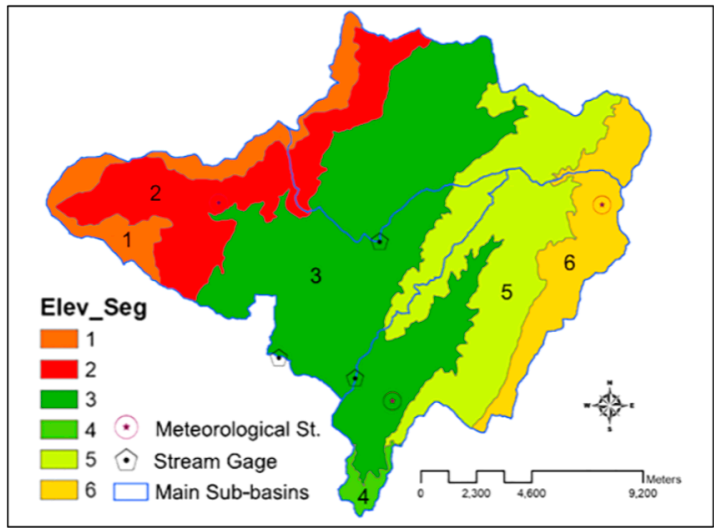

(b)

Figure 5. (a) Land survey of the elevation zones and (b) polygonal representation of the KırkgözeÇipak basin.

Table 3. Hypsometric values for the Kırkgöze-Çipak basin.

\begin{tabular}{cccc}
\hline Zone & $\begin{array}{c}\text { Hypsometric } \\
\text { Elevation }(\mathbf{m})\end{array}$ & Weather Station & $\begin{array}{c}\text { Weather Station } \\
\text { Altitude }(\mathbf{m})\end{array}$ \\
\hline 1 & 2777.236 & Güngörmez & 2444 \\
2 & 2509.433 & Köşk & 2042 \\
3 & 2098.651 & & \\
4 & 2297.814 & & 2887 \\
5 & 2454.838 & Radar & \\
6 & 2856.015 & & \\
\hline
\end{tabular}

As the hypsometric averages of zones 2, 3, and 6 are close to the altitudes of Güngörmez, Köşk, and the Radar stations, respectively, the average area-based precipitation calculations in these zones were taken directly at the respective stations. Based on the hypsometric elevations in other zones, a series of algorithms were run to obtain values in the direction of increasing or decreasing precipitation.

Firstly, the $15 \mathrm{~min}$ precipitation series recorded at each station were converted into daily total precipitation series while removing possible measurement errors. This daily sum is a precaution for the following algorithm (Table 4), especially for modeling the natural distribution of the interpolated or extrapolated zonal values of the convective characteristic heavy snowfalls observed at the station points. Otherwise, if the precipitation transition between stations exceeds the simulation time interval of $1 \mathrm{~h}$, the precipitation is only distributed on the station's zone. Therefore, the predictive values may take zero values mathematically on the transition zones noticed on field trips. The daily total precipitation values in zones 1, 4, and 5 were analyzed according to the flow chart in Table 4, which was prepared by considering the station locations given in Figure 5 and calculated within the designated rules.

After calculating the daily precipitation altitudes for zones 1,4 , and 5 , these altitudes were proportioned to the daily total precipitation altitude of zones 2,3 , and 6 , respec- 
tively, and precipitation coefficients were obtained. These coefficients were used for the conversion from the daily total precipitation altitude to the $15 \mathrm{~min}$ time interval. The first precipitation coefficient calculated to obtain the $15 \mathrm{~min}$ precipitation values for the 1st zone was multiplied by the 15 min precipitation series of the 2 nd zone. This procedure was also performed for zones 4 and 3 and zones 5 and 6, respectively. Thus, while maintaining the atmospheric homogeneity, the precipitation altitudes and timings of the $1 \mathrm{st}$, $4 \mathrm{th}$, and 5 th zones were adjusted with reference to the measurements taken from the 2 nd, $3 \mathrm{rd}$, and 5 th zones, respectively. The results obtained were increased to a one-hour time interval selected as the HEC-HMS simulation time interval and entered into the program.

Complete reliable data could not be obtained from the pluviographs during the winter months because the diluted antifreeze in the rain gauge froze after a certain period of time under the effect of the cold weather and excessive precipitation at both the Radar station and the Güngörmez station; the movable scale shaft which measures the amount of precipitation discharged from the reservoir did not work due to freezing and jamming, even when the antifreeze did not freeze. The data from the Köşk station showed that the freezing did not occur there due to the fact that the temperature was relatively higher than the other stations due to its lower altitude. As a result, much more reliable precipitation data were obtained there compared to the other stations during the winter months. Due to the problems encountered, especially at the Radar and Güngörmez stations, it was not found appropriate to use the data obtained from the rain gauges as direct precipitation data.

Table 4. The algorithm used for determining precipitation altitudes in the elevation zones where there was no station.

1st Zone

Calculated by extrapolating Köşk and Güngörmez station data

Calculated by interpolating the Köşk and Radar station data

5th Zone

Calculated by extrapolating the Köşk and Radar station data 1st Rule: If precipitation was observed at both stations, the total daily precipitation at the Köşk and Güngörmez stations was linearly extrapolated from the station altitudes to the average zone altitudes. If the extrapolation result was negative, the zonal precipitation altitude was taken as zero.

(If Köşk > 0 and Güngörmez > 0, then the trend was applied. If the trend $<0$, then 1 st zone $=0$ ).

2nd Rule: If there was no precipitation at Köşk but there was precipitation at the Güngörmez station, then precipitation altitude equals the Güngörmez station.

(If Köşk = 0 and Güngörmez > 0, then 1st zone = Güngörmez).

1st Rule: If Köşk $=0$, then 4 th zone $=0$.

2nd Rule: If Radar $=0$, then 4th zone $=$ Köşk.

3rd Rule: If Köşk > 0 and Radar > 0, then the trend is applied. If Trend $<0$, then 4 th zone $=$ Köşk .

1st Rule: If Kössk $=0$ and Radar $\geq 5 \mathrm{~mm}$, then the trend is applied.

2nd Rule: If Köşk $=0$ and Radar $<5 \mathrm{~mm}$, then 5th zone $=0$. 3rd Rule: If Köşk $<5 \mathrm{~mm}$ and Radar $=0$, then 5th zone $=0$. 4th Rule: If Köşk $\geq 5 \mathrm{~mm}$ and Radar $=0$, then the trend is applied by checking meteorological data from the Güngörmez and Radar stations.

5th Rule: If Köşk > 0 and Radar > 0, then the trend is applied.

In winter, while the precipitation series were formed during the snow accumulation period, the differences in the 24-h averages of the snow-water equivalent altitudes (SWE) obtained from the snow pillows were taken. If the difference between these daily averages was positive, the SWE difference for that day was added to the station as precipitation. The timing of precipitation was adjusted in correlation with simultaneous albedo and humidity data, taking into account the effect of snow drift, while the distribution of precipitation during the day was determined by the amount of increase in the measured SWE during the day. 


\subsection{Snowmelt Model}

In HEC-HMS (Version 4.2.1), there are two snowmelt modeling options. One of them is the gridded temperature index method and the second is the temperature index method, which is the method that was used in this study. The temperature index method is an extension of the degree-day approach to modeling a snowpack. A typical approach to the degree day is to have a fixed amount of snowmelt for each degree above freezing. This method includes a conceptual representation of the cold energy stored in the pack along with a limited memory of past conditions and other factors to compute the amount of melt for each degree above freezing. As the snowpack internal conditions and atmospheric conditions change, the melt coefficient also changes [18].

If the main source of energy in the spring is not the solar irradiance, snowmelt can be more effectively and simply computed using a temperature index model [10,68-73]. In hydrologics, an index is a meteorological or hydrological variable. Changes in the variable are associated with those in the parameter it is estimating, and which are more easily measured than the actual parameter. Either a coefficient (such as a degree-day factor) or a formula for more complex linear or curvilinear functions (such as the antecedent temperature index - melt rate function) may be used to describe this index relationship. Depending upon changing associated factors, it may be either constant or variable. Spatial and temporal basin value point measurements are represented by the index where average fixed relationships are known to exist between the measured values and basin values. However, snow accumulation and melting topics are complex, and the data required for physically-based energy budget calculations are comprehensive and challenging to obtain [68].

Some temperature index models require the snowpack's melt rate to be characterized $[74,75]$. This melt rate can be stated differently. One example is to express changes in the melting rate as a function of air temperature accumulation over several warm days for melting snow. This is achieved by using the ATIMR (antecedent temperature index-melt rate) function to determine the melt rate for a certain antecedent temperature index. Snow physics indicate that melting rates increase throughout the season due to both metamorphic processes causing ice crystal consolidation and the snowpack producing more water over time [24].

Past modeling studies have generally been based on a theoretical constant ATIMR curve generated by the USACE (1991) and used for characterization of melt rates [19-22,76,77]. The theoretical curve was included in the SSARR model in 1991. The SSARR guide [78] ATIMR values are shown in Table 5.

Table 5. Tabulation of melt rate as a function of ATIMR.

\begin{tabular}{cc}
\hline ATIMR: ${ }^{\circ}$ F-Day $\left({ }^{\circ} \mathbf{C}\right.$-Day) & Melt Rate: in $/{ }^{\circ}$ F-Day $\left(\mathrm{cm} /{ }^{\circ}\right.$ C-Day) \\
\hline $0(0)$ & $0.025(0.12)$ \\
$100(55.56)$ & $0.03(0.13)$ \\
$200(111.11)$ & $0.05(0.23)$ \\
$300(166.67)$ & $0.04(0.18)$ \\
$1000(555.56)$ & $0.04(0.18)$ \\
\hline
\end{tabular}

For the values in the customary U.S. system, please see the SSARR model guide in Appendix D, p. 17; the methodology used to calculate the metric system results is presented by Şengül and İspirli (2021) in detail.

Modified melting rates have been used by many studies using the hypothetical ATIMR function of Table 5 during calibration; however, a commonly observed shortcoming in published literature is that no particular data is used to directly estimate the ATIMR curve. Sometimes the hypothetical ATIMR curve is taken as a starting point for snowpack simulations and different scenarios used to modify the curve to improve simulated results during calibration [19-22]. Sometimes the theoretical ATIMR curve is not modified, but an additional rate is applied to the melting rate obtained from the ATIMR curve in proportion to the varying rate over time [77,78]. However, the physical meaning of widely used ATIMR functions is important in hydrologic modeling studies [25]. 
It is necessary to refer to published literature or land data to understand how a generalized hypothetical ATIMR curve was generated. The values in Table 5 are thought to be a visualization of an ATIMR function generated from the authors' information-as a resulting of engineering decisions implemented in 1991 at the start of snowmelt modeling studies-from the documented results of land data or by undocumented means. However, now a review of this parameter is necessary to determine the reliability of regional snowmelt predictions [24]. Following a comprehensive review of published literature, no study was found carrying out a formal validation of the ATIMR parameter using observed data other than the studies by Şengül and İspirli (2021) and Fazel et al. (2014). The first of these studies was a preliminary study of snowmelt modeling in this basin. The methodology determined by Fazel et al. (2014) represented only one year of data for certain single-point locations. When the HEC-HMS program performs full hydrological simulations on catchments it uses the temperature index methodology and restricts researchers to one ATIMR function for the whole basin. It is therefore necessary to develop an optimal area-based average ATIMR function later on and is hydrologically significant for modeling snowmelt-originated flows originating in complex mountainous terrains.

The HEC-HMS model program is capable of generating grid or polygonal area-based hydrological simulation models. The HEC-HMS program allows the creation of a meteorological model to represent the meteorological boundary conditions of a basin's physical behavior and some of the spatial and area-based variables distributed over that basin. However, published literature highlights a significant deficiency in the polygonal-based modeling of the HEC-HMS model program that is widely used and part of this study, in that only one meteorological model can be used for a basin model. Consequently, eighteen hydrological models must be created for eighteen sub-basins [79]. The meteorological model applies the climatic conditions represented by precipitation, evapotranspiration, and snowmelt, based upon the methods chosen. In basins where there are large differences in altitudes, it is impractical to apply one set of snowmelt parameters-such as the melt rate or snowmelt threshold temperature-over all the locations because of a range of factors that can include radiation effects, wind conditions, and others [70]. Snowmelt parameters would not be constant for a basin that exhibited a wide range of altitudes. This would include variables such as the water capacity of the snowpack and the threshold temperature at which precipitation occurs as snow or rain. In order to take this into consideration when the entire basin is modeled in one go using the polygonal-based method in HEC-HMS, it is necessary to enhance the temperature index model with area-based average ATIMR functions to cope with restricted availability of parameters and the increasing demand for accurate estimates for melt rates in both spatial and temporal terms.

The study conducted by Fazel et al. (2014) was originally the only approach to calculate the physical significance of the ATIMR curve beyond its manual calibration. As that study mentioned, although the ATI equation (the antecedent temperature index component of the ATIMR function) was provided, the SSARR guide did not describe the method used to generate the hypothetical ATIMR curve. The method provided by Fazel et al. (2014) for one snowmelt period at distinct station locations was subsequently developed and applied by Şengül and İspirli (2021) to create ATIMR curves specific to the KırkgözeÇipak Basin using hourly temperatures and snow-water equivalent (SWE) data using error analysis methods recommended by Bombardelli and García (2003) obtained from the three meteorology and snow observation stations. The comparisons of both characteristics and statistical information from the snowmelt component simulation results of HEC-HMS, and the observed multivariate spatial-temporal SWE values of the region, shows a very high correlation between the generated ATIMR functions and the default SSARR values used in published literature [25].

Calibration of the other parameters used in the meteorological model used in the temperature index method were performed by considering the values in published literature $[48,78]$, namely (PX temperature $=2{ }^{\circ} \mathrm{C}$, base temperature $=0{ }^{\circ} \mathrm{C}$, wet melt rate $=3.2 \mathrm{~mm} /{ }^{\circ} \mathrm{C}$-day, rain rate limit $=1.3 \mathrm{~mm} /$ day, $\mathrm{ATI}$-melt rate coefficient $=0.98$, cold 
limit $=0 \mathrm{~mm} /$ day, ATI cold rate coefficient $=0$, water capacity $=20 \%$, ground melt $=0 \mathrm{~mm} /$ day) . As a result, the SWE simulations necessary to arrive efficiently at the final water budget calculations were optimized throughout the basin [25].

The area-based common ATIMR function (Figure 6) is meant to represent all three point ATIMR functions, so point values should be examined together and in relation to their land and snow altitude. For example, at the low-altitude Köşk Station, due to the low amount of snowpack and early melting, there was a limited ATI value, and the ATI values of stations at higher altitudes were increased in proportion to the area-based ATI values exceeding that threshold. The values of the point and final area-based ATIMR functions measured in the Kırkgöze-Çipak Basin are shown in Table 6. The HEC-HMS modeled SWE results using the common area-based ATIMR function for the different stations are shown in Figure 7. The area-based ATIMR value of $125^{\circ} \mathrm{C}$-day-the last value in Table 6 -is the cumulative ATI value for which the snow observed over the specified period at all station locations had completely melted. For rainfall-runoff studies to be carried out across the basin, the value had to be increased and extrapolated to account for the greater snow depths observed at higher altitudes by modifying precipitation series [25].

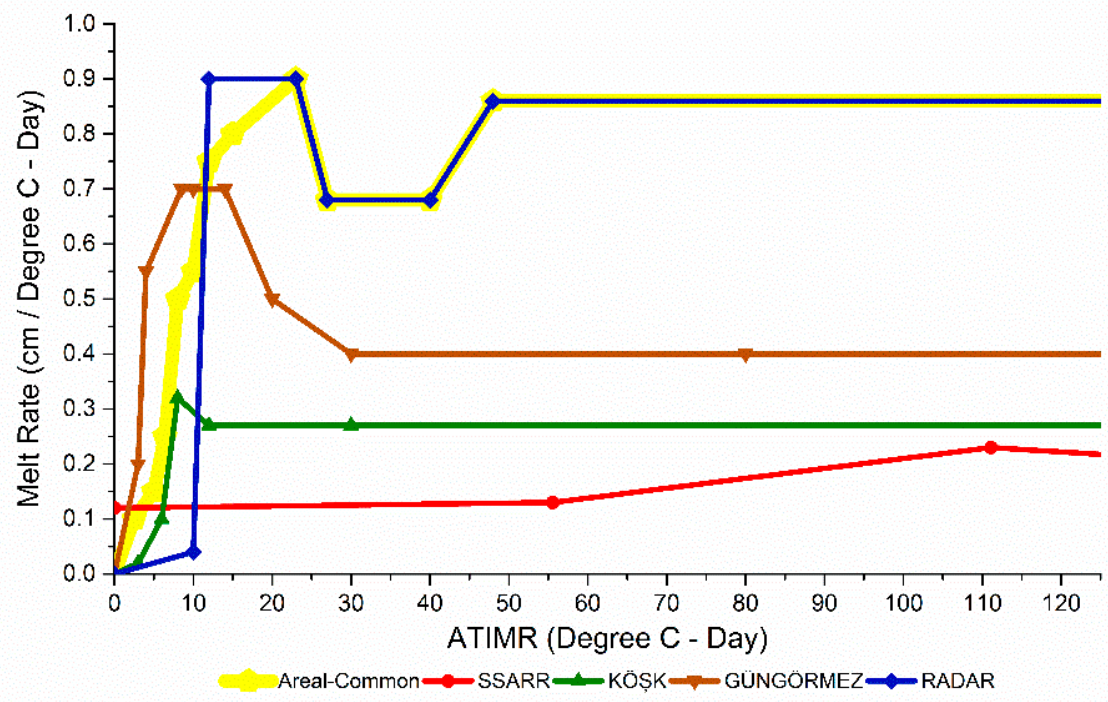

Figure 6. Point and area-based ATIMR curves.

Table 6. Point and area-based common ATIMR function for the Kırkgöze-Çipak Basin.

\begin{tabular}{|c|c|c|c|c|c|c|c|}
\hline \multicolumn{6}{|c|}{ Point ATIMR Curves } & \multicolumn{2}{|c|}{ Areal-Common ATIMR Curve } \\
\hline \multicolumn{2}{|c|}{$\begin{array}{l}\text { Köşk Station } \\
(2019 \mathrm{~m})\end{array}$} & \multicolumn{2}{|c|}{$\begin{array}{c}\text { Güngörmez Station } \\
(2454 \mathrm{~m})\end{array}$} & \multicolumn{2}{|c|}{$\begin{array}{l}\text { Radar Station } \\
\quad(2891 \mathrm{~m})\end{array}$} & \multicolumn{2}{|c|}{ Basin-Wide } \\
\hline $\begin{array}{c}\text { ATIMR } \\
\left({ }^{\circ} \mathrm{C}-\text { Day }\right)\end{array}$ & $\begin{array}{c}\text { Melt Rate } \\
\left(\mathrm{cm} /{ }^{\circ} \mathrm{C} \text {-Day }\right)\end{array}$ & $\begin{array}{c}\text { ATIMR } \\
\left({ }^{\circ} \text { C-Day) }\right.\end{array}$ & $\begin{array}{c}\text { Melt Rate } \\
\left(\mathrm{cm} /{ }^{\circ} \mathrm{C}-\text { Day }\right)\end{array}$ & $\begin{array}{c}\text { ATIMR } \\
\left({ }^{\circ} \text { C-Day) }\right.\end{array}$ & $\begin{array}{c}\text { Melt Rate } \\
\left(\mathrm{cm} /{ }^{\circ} \text { C-Day) }\right.\end{array}$ & $\begin{array}{c}\text { ATIMR } \\
\left({ }^{\circ} \text { C-Day }\right)\end{array}$ & $\begin{array}{c}\text { Melt Rate } \\
\text { (cm/ } /{ }^{\circ} \text { C-Day) }\end{array}$ \\
\hline 0 & 0.00 & 0 & 0.00 & 0 & 0.00 & 0 & 0.00 \\
\hline 3 & 0.02 & 3 & 0.02 & 10 & 0.04 & 2.5 & 0.10 \\
\hline 6 & 0.10 & 4 & 0.55 & 12 & 0.90 & 5 & 0.15 \\
\hline 8 & 0.32 & 8.5 & 0.70 & 23 & 0.90 & 6.4 & 0.25 \\
\hline 12 & 0.27 & 10 & 0.70 & 27 & 0.68 & 8 & 0.50 \\
\hline \multirow[t]{8}{*}{$30^{+}$} & 0.27 & 20 & 0.50 & 40 & 0.68 & 10 & 0.55 \\
\hline & & 30 & 0.40 & 48 & 0.86 & 12 & 0.75 \\
\hline & & $80^{+}$ & 0.40 & $125^{+}$ & 0.86 & 15 & 0.80 \\
\hline & & & & & & 23 & 0.90 \\
\hline & & & & & & 27 & 0.68 \\
\hline & & & & & & 40 & 0.68 \\
\hline & & & & & & 48 & 0.86 \\
\hline & & & & & & $125^{+}$ & 0.86 \\
\hline
\end{tabular}




\subsection{Calibration Strategy}

Manual parameter calibration was preferred in this study due to the karstic behavior of the basin. Manual calibration begins with an appropriate estimation of the initial parameters to run the model. The Kırkgöze-Çipak model was developed on a daily timescale over a 3-year period between the calibration (2008 to 2010) and validation (2010 to 2011) periods. In the study area, there were three stream gauge stations, namely KarasuÇipak (DSİ, 21-01), Büyükçay-Karagöbek (DSİ, 21-168), and Köşk Dere-Köşk (DSİ, 21-152); these stations regularly performed hydrometric measurements. Calibration was carried out using the records of these stream gauge stations to simulate the flow in the simulations performed with HEC-HMS. The locations of meteorological stations and stream gauge stations are shown in Figure 3. The simulation was initiated at the beginning of autumn when the soil was almost dry. Therefore, the initial storage was assumed to be empty. Initial storage has an effect on the simulated hydrograph from a few days to a maximum of a few months [80]. However, they are insignificant for long-term water resource planning. After running the simulation, the simulated results were compared with the data observed from the stream gauge stations.

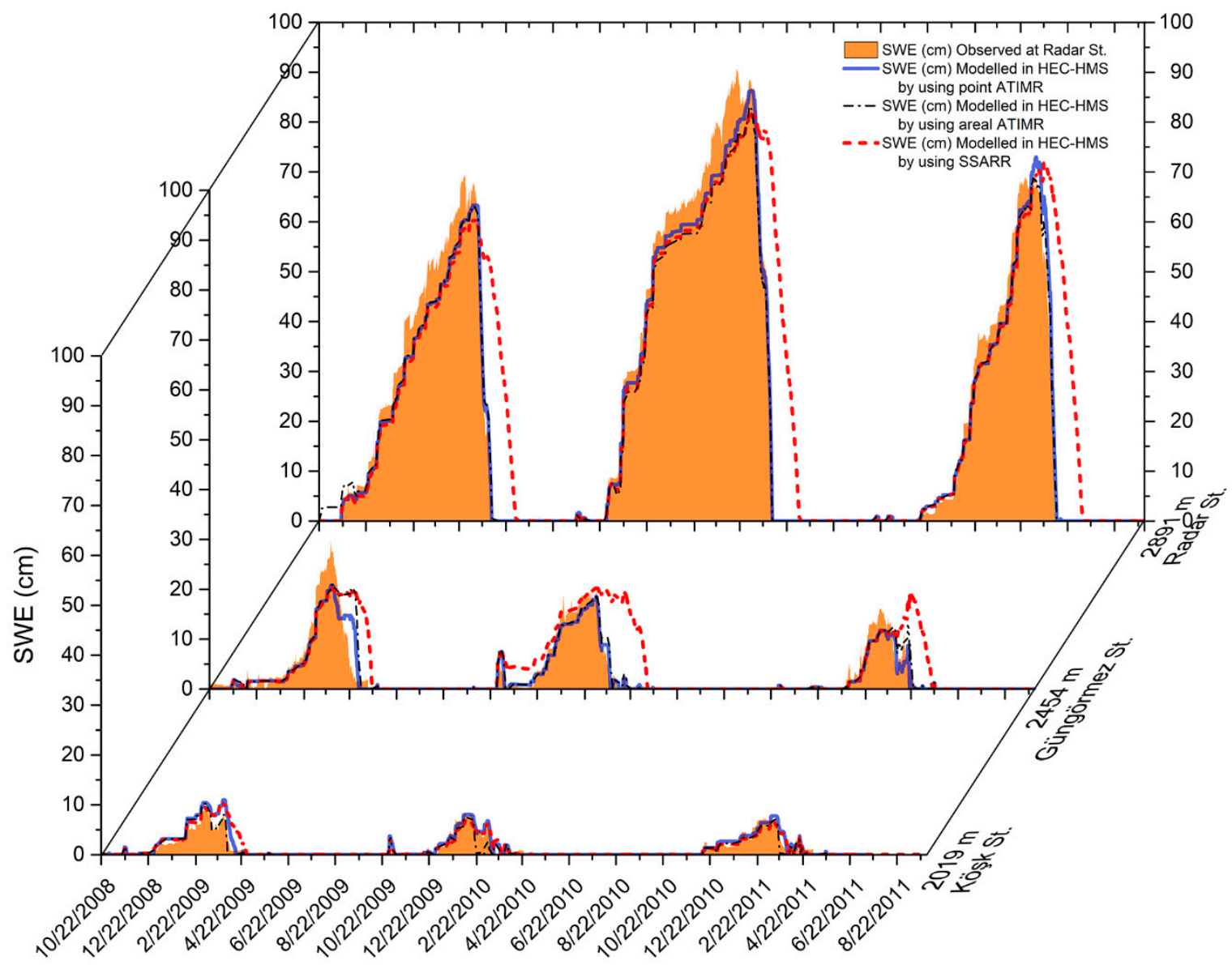

Figure 7. Snow-water equivalent (SWE) simulations computed with typical SSARR, point and common-areal ATIMR functions.

\section{Results}

The Kırkgöze-Çipak Basin is one where there is a lot of snowfall. In modeling the transformation process from snowfall into runoff, primarily SWE simulations were performed. For this reason, using the temperature index method, the data from the three meteorology stations at different altitudes and exposures on the basin were taken as points, and simulations were conducted. The validation criteria for these simulations are presented in Table 7. However, the fact that the basin has altitude and exposure differences due 
to its complex topographical structure, and because the HEC-HMS has to simulate the entire basin with a single meteorological model, SWE simulations needed to be performed spatially while normally point simulations are performed for SWE simulations. This is because if the snow-water equivalent simulations are not performed properly, the snowmelt runoff process cannot be modeled properly. For this reason, a common melting parameter was developed for the three stations and the validity of the results is shown. The typical SSARR function and the common-areal melting parameter developed to be used in this and similar studies, along with the snow-water equivalent simulations at station locations, are compared in Figure 7.

After obtaining accurate snow-water equivalent simulations (Figure 7), basin-wide snowmelt runoff simulations were performed. As the stream gauge stations Köşk DereKöşk (DSİ 21-152), Büyük Çay-Karagöbek (DSİ 21-168), and Karasu-Çipak (DSİ 21-01) in the basin were at the lower and main exit points of the basin, the runoff series taken from these stations were used for calibration. The calibrated parameters of the sub-basins of the Kırkgöze-Çipak Basin are summarized in Table 8 on the scale of the main sub-basins. The improved final runoff simulation results obtained from the stream gauge station points are presented in Figure 8 along with the observed values. The similarity between the runoff obtained as a result of the hydrological simulation and the runoff values obtained from the stream gauge stations in the basin where the simulation is carried out is very important in terms of validating simulation accuracy and reliability.

Table 7. The $\mathrm{R}^{2}$, root mean square error (RMSE), Nash-Sutcliffe efficiency (NSE) and Kling-Gupta efficiency (KGE) values for modeled and actual SWE (using estimated point and area-based ATIMR functions with the default SSARR curve for the snow accumulations and melting periods from 2008 to 2011).

\begin{tabular}{|c|c|c|c|c|c|c|c|c|c|c|c|c|c|}
\hline & Station & $\begin{array}{l}\text { Point } \\
\mathbf{R}^{2}\end{array}$ & $\begin{array}{c}\text { Point } \\
\text { RMSE } \\
\text { (cm) }\end{array}$ & $\begin{array}{l}\text { Point } \\
\text { NSE }\end{array}$ & $\begin{array}{l}\text { Point } \\
\text { KGE }\end{array}$ & $\begin{array}{c}\text { Area- } \\
\text { Based } \\
\mathbf{R}^{2}\end{array}$ & $\begin{array}{c}\text { Area- } \\
\text { Based } \\
\text { RMSE } \\
(\mathrm{cm})\end{array}$ & $\begin{array}{c}\text { Area- } \\
\text { Based } \\
\text { NSE }\end{array}$ & $\begin{array}{c}\text { Area- } \\
\text { Based } \\
\text { KGE }\end{array}$ & $\underset{\mathbf{R}^{2}}{\text { SSARR }}$ & $\begin{array}{c}\text { SSARR } \\
\text { RMSE } \\
(\mathrm{cm})\end{array}$ & $\begin{array}{c}\text { SSARR } \\
\text { NSE }\end{array}$ & $\underset{\text { KGE }}{\text { SSARR }}$ \\
\hline $\begin{array}{l}\text { Calibration } \\
\text { period } \\
(2008-2010)\end{array}$ & $\begin{array}{c}\text { Köşk } \\
\text { Güngörmez } \\
\text { Radar }\end{array}$ & $\begin{array}{l}0.891 \\
0.887 \\
0.992 \\
\end{array}$ & $\begin{array}{l}1.351 \\
2.610 \\
4.590 \\
\end{array}$ & $\begin{array}{l}0.735 \\
0.876 \\
0.975 \\
\end{array}$ & $\begin{array}{l}0.624 \\
0.830 \\
0.887 \\
\end{array}$ & $\begin{array}{l}0.802 \\
0.770 \\
0.993 \\
\end{array}$ & $\begin{array}{l}1.276 \\
3.591 \\
5.487 \\
\end{array}$ & $\begin{array}{l}0.763 \\
0.766 \\
0.964 \\
\end{array}$ & $\begin{array}{l}0.861 \\
0.857 \\
0.851 \\
\end{array}$ & $\begin{array}{l}0.757 \\
0.385 \\
0.685 \\
\end{array}$ & $\begin{array}{c}1.601 \\
7.312 \\
16.433 \\
\end{array}$ & $\begin{array}{l}0.628 \\
0.030 \\
0.680 \\
\end{array}$ & $\begin{array}{l}0.678 \\
0.322 \\
0.760 \\
\end{array}$ \\
\hline $\begin{array}{l}\text { Validation period } \\
\quad(2010-2011)\end{array}$ & $\begin{array}{c}\text { Kössk } \\
\text { Güngörmez } \\
\text { Radar }\end{array}$ & $\begin{array}{l}0.781 \\
0.922 \\
0.970\end{array}$ & $\begin{array}{l}1.096 \\
1.834 \\
4.241\end{array}$ & $\begin{array}{l}0.752 \\
0.874 \\
0.970\end{array}$ & $\begin{array}{l}0.849 \\
0.730 \\
0.972\end{array}$ & $\begin{array}{l}0.840 \\
0.814 \\
0.982\end{array}$ & $\begin{array}{l}0.939 \\
2.235 \\
3.577\end{array}$ & $\begin{array}{l}0.818 \\
0.812 \\
0.979\end{array}$ & $\begin{array}{l}0.845 \\
0.871 \\
0.937\end{array}$ & $\begin{array}{l}0.761 \\
0.230 \\
0.582\end{array}$ & $\begin{array}{c}1.100 \\
6.207 \\
17.981\end{array}$ & $\begin{array}{c}0.751 \\
-0.449 \\
0.467\end{array}$ & $\begin{array}{l}0.773 \\
0.246 \\
0.646\end{array}$ \\
\hline $\begin{array}{c}3 \text { years period } \\
(2008-2011)\end{array}$ & $\begin{array}{c}\text { Köşk } \\
\text { Güngörmez } \\
\text { Radar }\end{array}$ & $\begin{array}{l}1.280 \\
0.891 \\
0.985\end{array}$ & $\begin{array}{l}0.858 \\
2.421 \\
4.476\end{array}$ & $\begin{array}{l}0.740 \\
0.878 \\
0.976\end{array}$ & $\begin{array}{l}0.701 \\
0.819 \\
0.904\end{array}$ & $\begin{array}{l}0.805 \\
0.779 \\
0.989\end{array}$ & $\begin{array}{l}1.185 \\
3.273 \\
4.931\end{array}$ & $\begin{array}{l}0.777 \\
0.776 \\
0.970\end{array}$ & $\begin{array}{l}0.874 \\
0.866 \\
0.868\end{array}$ & $\begin{array}{l}0.730 \\
0.361 \\
0.666\end{array}$ & $\begin{array}{c}1.469 \\
7.024 \\
16.966\end{array}$ & $\begin{array}{c}0.658 \\
-0.032 \\
0.648\end{array}$ & $\begin{array}{l}0.779 \\
0.318 \\
0.758\end{array}$ \\
\hline
\end{tabular}

Table 8. Initial and calibrated parameters for the three main sub-basins of the Kırkgöze-Çipak Basin.

\begin{tabular}{|c|c|c|c|c|c|c|c|c|}
\hline \multirow{2}{*}{ Sub-Model } & \multirow{2}{*}{ Method } & \multirow{2}{*}{ Parameter } & \multicolumn{2}{|c|}{ MS1 (Inc. 8 Sub-Basins) } & \multicolumn{2}{|c|}{ MS2 (Inc. 5 Sub-Basins) } & \multicolumn{2}{|c|}{ MS3 (Inc. 5 Sub-Basins) } \\
\hline & & & Initial & Calibrated & Initial & Calibrated & Initial & Calibrated \\
\hline \multirow{2}{*}{ Canopy } & \multirow{2}{*}{ Simple Canopy } & Initial Storage (\%) & 0 & 0 & 0 & 0 & 0 & 0 \\
\hline & & Max. Storage $(\mathrm{mm})$ & 2.5 & 6.77 & 2.5 & 4.23 & 2.5 & 5.97 \\
\hline \multirow{2}{*}{ Surface } & \multirow{2}{*}{ Simple Surface } & Initial Storage (\%) & 0 & 0 & 0 & 0 & 0 & 0 \\
\hline & & Max. Storage $(\mathrm{mm})$ & 5 & 6.67 & 5 & 6.67 & 5 & 6 \\
\hline \multirow{11}{*}{ Loss } & \multirow{11}{*}{$\begin{array}{l}\text { Soil Moisture } \\
\text { Accounting }\end{array}$} & Max. Infiltration $(\mathrm{mm} / \mathrm{h})$ & 2 & 1.208 & 2 & 1.95 & 2 & 1.73 \\
\hline & & Impervious (\%) & 0 & 0 & 0 & 0 & 0 & 0 \\
\hline & & Soil Storage (mm) & 100 & 71.93 & 100 & 101.83 & 100 & 66.97 \\
\hline & & Tension Storage (mm) & 50 & 41.25 & 50 & 33.55 & 50 & 45.64 \\
\hline & & Soil Percolation $(\mathrm{mm} / \mathrm{h})$ & 0.6 & 0.06 & 0.6 & 0.06 & 0.6 & 0.06 \\
\hline & & GW1 Storage $(\mathrm{mm})$ & 30 & 33.33 & 30 & 33.33 & 30 & 26.67 \\
\hline & & GW1 Percolation $(\mathrm{mm} / \mathrm{h})$ & 0.4 & 3.55 & 0.4 & 3.55 & 0.4 & 2.84 \\
\hline & & GW1 Coefficient (h) & 300 & 541.67 & 300 & 361.11 & 300 & 511.11 \\
\hline & & GW2 Storage (mm) & 40 & 35 & 40 & 35 & 40 & 35 \\
\hline & & GW2 Percolation $(\mathrm{mm} / \mathrm{h})$ & 0.3 & 2.67 & 0.3 & 2.67 & 0.3 & 2.13 \\
\hline & & GW2 Coefficient (h) & 400 & 433.33 & 400 & 288.88 & 400 & 408.88 \\
\hline
\end{tabular}


Table 8. Cont.

\begin{tabular}{|c|c|c|c|c|c|c|c|c|}
\hline \multirow{2}{*}{ Sub-Model } & \multirow{2}{*}{ Method } & \multirow{2}{*}{ Parameter } & \multicolumn{2}{|c|}{ MS1 (Inc. 8 Sub-Basins) } & \multicolumn{2}{|c|}{ MS2 (Inc. 5 Sub-Basins) } & \multicolumn{2}{|c|}{ MS3 (Inc. 5 Sub-Basins) } \\
\hline & & & Initial & Calibrated & Initial & Calibrated & Initial & Calibrated \\
\hline \multirow{2}{*}{ Transform } & \multirow{2}{*}{$\begin{array}{l}\text { Clark Unit } \\
\text { Hydrograph }\end{array}$} & Time of Concentration (h) & 2.386 & 2.386 & 2.528 & 2.529 & 2.176 & 2.175 \\
\hline & & Storage Coefficient (h) & 200 & 80 & 200 & 80 & 200 & 300 \\
\hline \multirow{12}{*}{ Base Flow } & \multirow{12}{*}{$\begin{array}{l}\text { Constant } \\
\text { Monthly }\end{array}$} & January $\left(\mathrm{m}^{3} / \mathrm{s}\right)$ & 0.048 & 0.048 & 0.065 & 0.065 & 0.056 & 0.056 \\
\hline & & February $\left(\mathrm{m}^{3} / \mathrm{s}\right)$ & 0.074 & 0.074 & 0.099 & 0.099 & 0.079 & 0.079 \\
\hline & & $\operatorname{March}\left(\mathrm{m}^{3} / \mathrm{s}\right)$ & 0.121 & 0.121 & 0.158 & 0.158 & 0.143 & 0.143 \\
\hline & & April $\left(\mathrm{m}^{3} / \mathrm{s}\right)$ & 0.183 & 0.183 & 0.221 & 0.221 & 0.233 & 0.233 \\
\hline & & $\operatorname{May}\left(\mathrm{m}^{3} / \mathrm{s}\right)$ & 0.226 & 0.226 & 0.205 & 0.205 & 0.272 & 0.272 \\
\hline & & June $\left(\mathrm{m}^{3} / \mathrm{s}\right)$ & 0.123 & 0.092 & 0.133 & 0.099 & 0.161 & 0.241 \\
\hline & & July $\left(\mathrm{m}^{3} / \mathrm{s}\right)$ & 0.084 & 0.063 & 0.097 & 0.072 & 0.112 & 0.126 \\
\hline & & August $\left(\mathrm{m}^{3} / \mathrm{s}\right)$ & 0.062 & 0.046 & 0.075 & 0.056 & 0.080 & 0.060 \\
\hline & & September $\left(\mathrm{m}^{3} / \mathrm{s}\right)$ & 0.054 & 0.041 & 0.067 & 0.050 & 0.071 & 0.053 \\
\hline & & October $\left(\mathrm{m}^{3} / \mathrm{s}\right)$ & 0.053 & 0.053 & 0.067 & 0.067 & 0.069 & 0.069 \\
\hline & & November $\left(\mathrm{m}^{3} / \mathrm{s}\right)$ & 0.050 & 0.050 & 0.065 & 0.065 & 0.064 & 0.064 \\
\hline & & December $\left(\mathrm{m}^{3} / \mathrm{s}\right)$ & 0.046 & 0.046 & 0.060 & 0.060 & 0.058 & 0.058 \\
\hline
\end{tabular}

It was observed that the simulations from the three-year time period simulated the real values very well both in temporal terms and statistically on the basin basis. $\mathrm{R}^{2}$, RMSE, NSE, and KGE values of runoff simulations at stream gauge stations are presented in Table 9.

Table 9. $\mathrm{R}^{2}$, RMSE, NSE, and KGE values of flow rate simulations at the stream gauge stations.

\begin{tabular}{ccccc}
\hline Station & $\mathbf{R}^{\mathbf{2}}$ & RMSE & NSE & KGE \\
\hline 21-01 (Karasu-Çipak) & 0.840 & 2.144 & 0.817 & 0.748 \\
21-152 (Köşk Dere-Köşk) & 0.656 & 1.967 & 0.431 & 0.262 \\
21-168 (Büyükçay-Karagöbek) & 0.586 & 1.359 & 0.406 & 0.265 \\
\hline
\end{tabular}




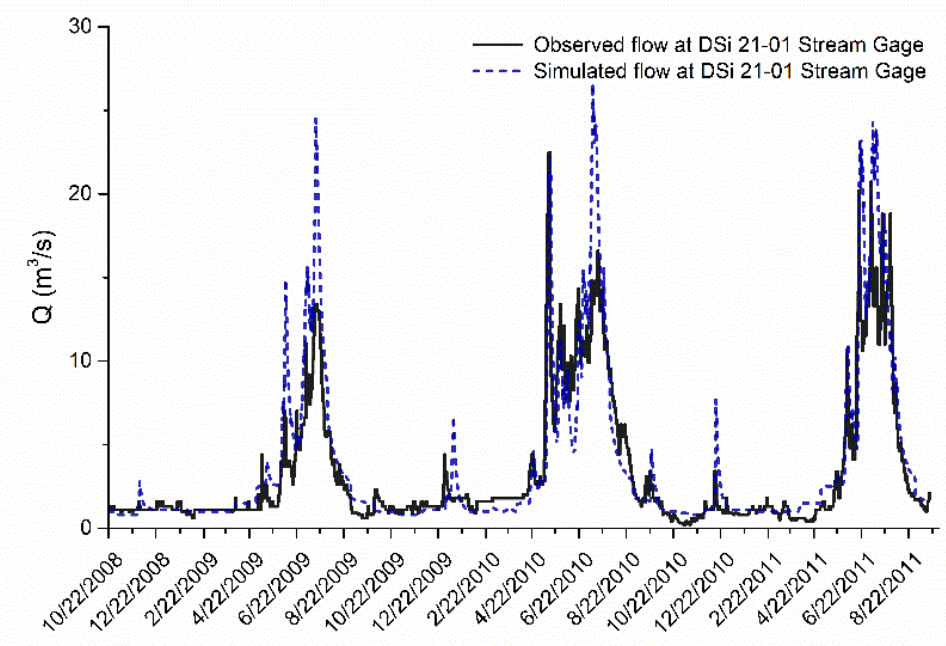

(a)

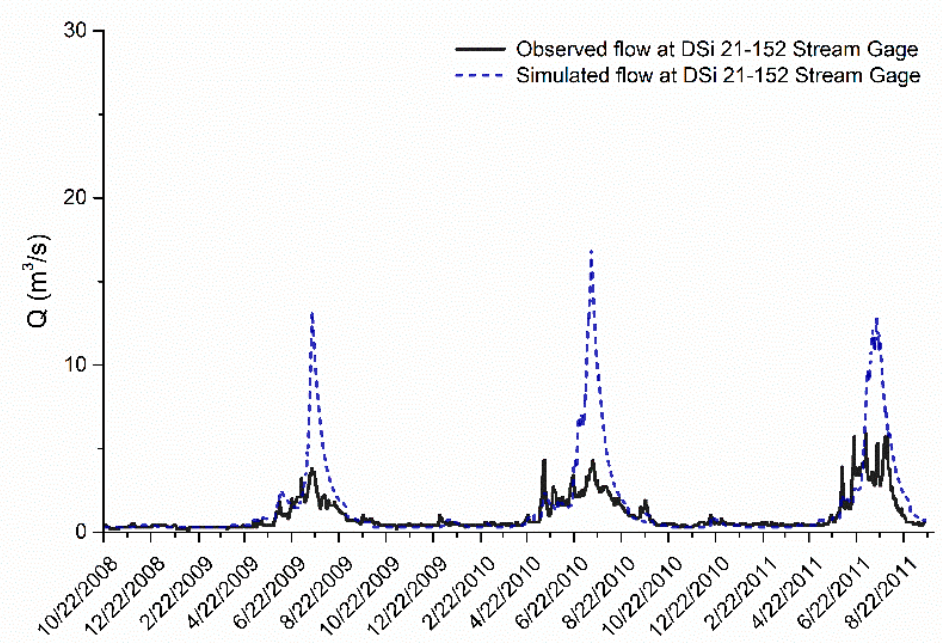

(b)

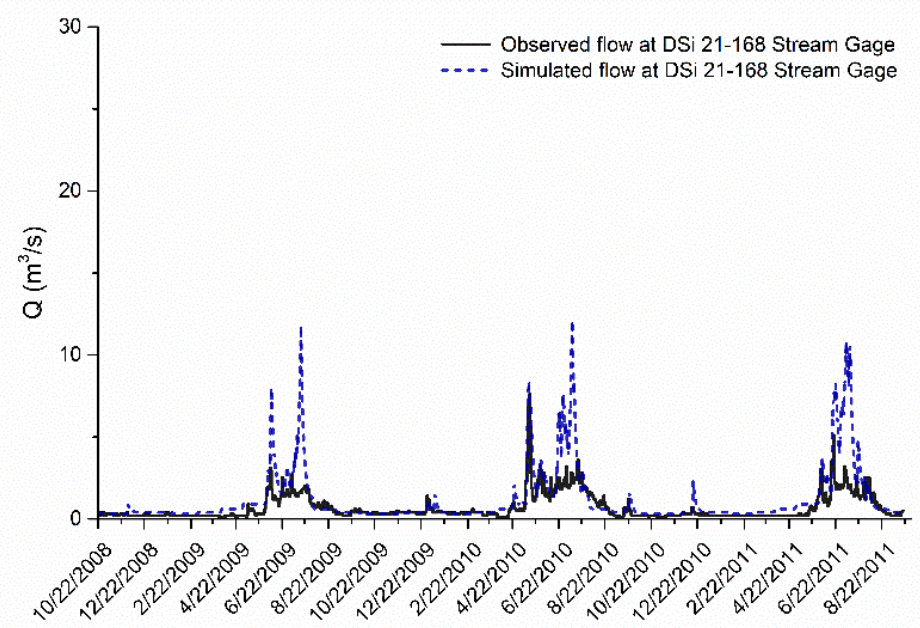

(c)

Figure 8. Observed and simulated flow rates at the (a) Karasu-Çipak (DSİ 21-01), (b) Köşk Dere-Köşk (DSİ 21-152), and (c) Büyük Çay-Karagöbek (DSİ 21-168) stream gauge stations. 


\section{Discussion}

The observation of the stream hydrographs and the statistical analyses showed that the flowrate simulations at the basin outlet (DSİ 21-01) were better than at the other stream gauge stations (DSI 21-152, DSI 21-168). It was observed that the simulations for the peak flow rates during the melting periods at these two stream gauge stations inside the study basin were higher than the measured values. However, the fact that the water budget calculations for the main basin outlet can only be obtained with the exaggerated simulations of related hydrographs indicates the presence of karstic formations in the basin. As a matter of fact, the presence of many springs observed in the study basin due to the general hydrogeological formations in the basin, and the fact that the groundwater model does not exhibit linear behavior, confirms that the land has a karstic character $[23,81]$. For this reason, while performing HEC-HMS model calibrations, the automatic calibration process was initially followed up to a point but later abandoned. Still, a manual calibration process was used in the study to reveal the actual behavior of the basin in general. In hydrological modeling studies, a model that reflects the basin characteristics well is expected to have good statistical indicators such as $\mathrm{R}^{2}$ and RMSE or metric scores such as the Nash-Sutcliffe efficiency (NSE) and the Kling-Gupta efficiency (KGE). However, the reverse may not always be accurate [82-84]. Considering the modeling limitations for karstic behavior in the HEC-HMS model, this study may not provide characteristic flow simulations at the main basin outlet by automatically optimizing the parameters while evaluating the statistical and metric results of flow rate simulations with observation gauges inside the basin. In this case, a physically meaningful manual calibration of all the natural events that may cause the change in the flow simulations for the main basin outlet is required. However, it should not be ignored that the model results obtained with a more intense effort can improve the results much more; it has been concluded that the calibration and validation period results are sufficient. Undoubtedly, many clues can be brought about the actual basin behavior with the hydrological models established in the computer environment. The studies carried out will help the development of new techniques that can fully model natural behavior at every point of the watershed and for selecting or combining the appropriate models.

Similarly, in the manual calibration process of snow-water equivalent simulations, each characteristic detail of the SWE curve, especially during the melting period, was primarily modeled in a physically meaningful way to analyze the events for future studies. For example, the $\mathrm{R}^{2}$ values calculated on the point scale for the Radar station in Table 7 are slightly lower than the values calculated on the areal-based values, unexpectedly, because the manually selected parameters also try to better simulate the critical rain on snow events during the melting period on high elevation zones [25].

\section{Conclusions}

In this study, basin characterization preprocessing was conducted with GIS-based HEC-GeoHMS, and basin and meteorological models were created. The outputs obtained were used as inputs for the hydrological simulation program HEC-HMS. The simulations for the years 2008 to 2011 were carried out with the model developed for the runoff of the Kırkgöze-Çipak basin and its sub-basins, where a significant part of the annual total runoff (70 to $80 \%$ ) is formed by snowmelt.

The boundaries of the chosen Kırkgöze-Çipak basin study area were determined using the HEC-GeoHMS program, and its characterization was carried out and the model inputs were obtained for the HEC-HMS application. When determining the boundaries of a basin and its sub-basins, the outer basin boundary, and the surface stream network, the longest flow path, etc., are determined and then the whole basin is divided into sub-basins. After that, the physical parameters of these sub-basins are determined. In the next stage, a meteorological model definition is created for the climate characterization of the sub-basins.

The snowmelt rate function, which is the most effective parameter for the simulation of the snow-water equivalent during the implementation of the snowmelt model with the basin temperature index method, was primarily obtained from the locations of the three 
meteorology stations in the study basin. Then, these curves that were originally obtained as points were reduced to a single curve representing the study basin in general. Considering the characteristic behavior of point and areal snow-water equivalent simulations, as well as $\mathrm{R}^{2}$ and RMSE values, the parameters required for snow-water equivalent simulation-one of the most important steps in simulating the flow rate for a basin where there is a lot of snowfall-were successfully integrated into the runoff model. With this physically-based approach, it has also been shown that regional studies on snow can be carried out more reliably and quickly.

After the basin-wide snow-water equivalent simulations were successfully performed, a hydrological model was created with HEC-HMS, and the runoff outputs of this model were correlated with the observed data from Köşk Dere-Köşk (DSİ 21-152), Büyük ÇayKaragöbek (DSİ 21-168), and Karasu-Çipak (DSİ 21-01) stream gauge stations, and thus model calibration was performed.

Although the Kırkgöze-Çipak Basin is small in terms of surface area, it is a basin with a large altitude range. It is inevitable that meteorological variability will be high in such a basin. In hydrological model studies, it is very important for the accuracy and reliability of the simulations that the meteorological data distribution across the basin is in line with the real values in the field. Having the Köşk, Güngörmez, and Radar meteorology stations, which are located at the appropriate altitude and location in the basin, ensures that the meteorological variable distribution was as close to reality as possible, and it also maximized the reliability of the hydrological model parameters obtained from the HEC-HMS.

As a result, in this study, it has been shown that, with the HEC-HMS hydrological model, flow rate simulations can be performed with very good $\mathrm{R}^{2}$ and RMSE values and also NSE and KGE scores at the outlet of the snow-dominated, mountainous Kirkgöze Basin, which has a very complex topography. It is believed that the model parameters obtained and the methodology used will be a source for hydrological model studies to be carried out in similar mountain basins and help authorities to use water resources well, not only regionally, but also nationally and internationally.

Author Contributions: All authors contributed to the study conception and design. Conceptualization: S.Ş. and M.N.İ., Methodology: S.Ş. and M.N.İ., Software: S.Ş. and M.N.İ., Validation and Formal analysis: S.Ş. and M.N.İ., Writing-Original Draft: S.Ş. and M.N.İ., Writing-Review and Editing: S.Ş., Visualization: S.Ş., Supervision: S.Ş. All authors have read and agreed to the published version of the manuscript.

Funding: This study has not received any funding from any institution/organization.

Data Availability Statement: All the data are provided in this paper, and no additional data are available to provide.

Conflicts of Interest: The authors declare no conflict of interest.

\section{References}

1. Hassan, F. Water History for Our Times. In International Hydrological Programme; UNESCO: Paris, France, $2011 ;$ p. 122.

2. Tekeli, A.E.; Akyürek, Z.; Arda Şorman, A.; Şensoy, A.; Ünal Şorman, A. Using MODIS Snow Cover Maps in Modeling Snowmelt Runoff Process in the Eastern Part of Turkey. Remote Sens. Environ. 2005, 97, 216-230. [CrossRef]

3. Yucel, I.; Guventurk, A.; Sen, O.L. Climate Change Impacts on Snowmelt Runoff for Mountainous Transboundary Basins in Eastern Turkey. Int. J. Climatol. 2015, 35, 215-228. [CrossRef]

4. Stewart, I.T. Changes in Snowpack and Snowmelt Runoff for Key Mountain Regions. Hydrol. Process. Int. J. 2009, 23, 78-94. [CrossRef]

5. Sood, A.; Smakhtin, V. Global Hydrological Models: A Review. Hydrol. Sci. J. 2015, 60, 549-565. [CrossRef]

6. Dong, C. Remote Sensing, Hydrological Modeling and in Situ Observations in Snow Cover Research: A Review. J. Hydrol. 2018, 561, 573-583. [CrossRef]

7. Dhami, B.S.; Pandey, A. Comparative Review of Recently Developed Hydrologic Models. J. Indian Water Resour. Soc. 2013, 33, 34-41.

8. Zhou, Y.; Cui, Z.; Lin, K.; Sheng, S.; Chen, H.; Guo, S.; Xu, C.-Y. Short-Term Flood Probability Density Forecasting Using a Conceptual Hydrological Model with Machine Learning Techniques. J. Hydrol. 2022, 604, 127255. [CrossRef] 
9. Wurbs, R.A. Dissemination of Generalized Water Resources Models in the United States. Water Int. 1998, 23, 190-198. [CrossRef]

10. Yilmaz, A.G.; Imteaz, M.A.; Ogwuda, O. Accuracy of HEC-HMS and LBRM Models in Simulating Snow Runoffs in Upper Euphrates Basin. J. Hydrol. Eng. 2012, 17, 342-347. [CrossRef]

11. Chen, Y.; Li, W.; Fang, G.; Li, Z. Review Article: Hydrological Modeling in Glacierized Catchments of Central Asia-Status and Challenges. Hydrol. Earth Syst. Sci. 2017, 21, 669-684. [CrossRef]

12. Anderson, E.A. Snow Accumulation and Ablation Model-SNOW-17; NOAA's National Weather Service Hydrology Laboratory NWSRFS User Manual; NOAA: Washington, DC, USA, 2006; p. 61.

13. Zhou, J.; Pomeroy, J.W.; Zhang, W.; Cheng, G.; Wang, G.; Chen, C. Simulating Cold Regions Hydrological Processes Using a Modular Model in the West of China. J. Hydrol. 2014, 509, 13-24. [CrossRef]

14. Samaniego, L.; Kumar, R.; Attinger, S. Multiscale Parameter Regionalization of a Grid-Based Hydrologic Model at the Mesoscale. Water Resour. Res. 2010, 46. [CrossRef]

15. Burnash, R.J.C. The NWS River Forecast System-Catchment Modeling. In Computer Models of Watershed Hydrology; Water Resource Publication, LCC: Littleton, CO, USA, 1995; pp. 311-366.

16. Speers, D.D. SSARR Model. In Computer Models of Watershed Hydrology; Water Resource Publication, LCC: Littleton, CO, USA; pp. 367-394.

17. Scharffenberg, W.; Ely, P.; Daly, S.; Fleming, M.; Pak, J. Hydrologic Modeling System (HEC-HMS): Physically-Based Simulation Components. In Proceedings of the 2nd Joint Federal Interagency Conference, Las Vegas, NV, USA, 27 June-1 July 2010.

18. USACE. Hydrologic Modeling System HEC-HMS User's Manual; U.S. Army Corps of Engineers: Hanover, NH, USA, 2016.

19. OHRG. Osisko Hammond Reef Gold Project, Hydrology Technical Support Document VERSION 2, Project Number: 13-1118-0010, Document Number: DOC018. 2013. Available online: https://www.ceaa-acee.gc.ca/050/documents/P63174/123081E.Pdf (accessed on 10 November 2021).

20. Razmkhah, H.; Saghafian, B.; Ali, A.-M.A.; Radmanesh, F. Rainfall-Runoff Modeling Considnmering Soil Moisture Accounting Algorithm, Case Study: Karoon III River Basin. Water Resour. 2016, 43, 699-710. [CrossRef]

21. Dariane, A.B.; Javadianzadeh, M.M.; James, L.D. Developing an Efficient Auto-Calibration Algorithm for HEC-HMS Program. Water Resour. Manag. 2016, 30, 1923-1937. [CrossRef]

22. Darbandsari, P.; Coulibaly, P. Inter-Comparison of Lumped Hydrological Models in Data-Scarce Watersheds Using Different Precipitation Forcing Data Sets: Case Study of Northern Ontario, Canada. J. Hydrol. Reg. Stud. 2020, 31, 100730. [CrossRef]

23. Kourgialas, N.N.; Karatzas, G.P.; Nikolaidis, N.P. An Integrated Framework for the Hydrologic Simulation of a Complex Geomorphological River Basin. J. Hydrol. 2010, 381, 308-321. [CrossRef]

24. Fazel, K.; Scharffenberg, W.A.; Bombardelli, F.A. Assessment of the Melt Rate Function in a Temperature Index Snow Model Using Observed Data. J. Hydrol. Eng. 2014, 19, 1275-1282. [CrossRef]

25. Şengül, S.; İspirli, M.N. Estimation and Analysis of the Antecedent Temperature Index-Melt Rate (ATIMR) Function Using Observed Data from the Kırkgöze-Çipak Basin, Turkey. J. Hydrol. 2021, 598, 126484. [CrossRef]

26. Bombardelli, F.A.; García, M.H. Hydraulic Design of Large-Diameter Pipes. J. Hydraul. Eng. 2003, 129, 839-846. [CrossRef]

27. Şorman, A.A.; Şensoy, A.; Tekeli, A.E.; Şorman, A.Ü.; Akyürek, Z. Modelling and Forecasting Snowmelt Runoff Process Using the HBV Model in the Eastern Part of Turkey. Hydrol. Process. 2009, 23, 1031-1040. [CrossRef]

28. Yüksek, Ö. Reevaluation of Turkey's Hydropower Potential and Electric Energy Demand. Energy Policy 2008, 36, 3374-3382. [CrossRef]

29. Ogden, F.L.; Garbrecht, J.; DeBarry, P.A.; Johnson, L.E. GIS and Distributed Watershed Models. II: Modules, Interfaces, and Models. J. Hydrol. Eng. 2001, 6, 515-523. [CrossRef]

30. Emerson, C.H.; Welty, C.; Traver, R.G. Watershed-Scale Evaluation of a System of Storm Water Detention Basins. J. Hydrol. Eng. 2005, 10, 237-242. [CrossRef]

31. Leavesley, G.H.; Lichty, R.W.; Troutman, B.M.; Saindon, L.G. Precipitation-Runoff Modeling System: User's Manual. Water-Resour. Investig. Rep. 1983, 83, 207.

32. Akyürek, Z.; Şorman, A.Ü. Monitoring Snow-Covered Areas Using NOAA-AVHRR Data in the Eastern Part of Turkey. Hydrol. Sci. J. 2002, 47, 243-252. [CrossRef]

33. Yerdelen, C.; Acar, R. Study on Prediction of Snowmelt Using Energy Balance Equations and Comparing with Regression Method in the Eastern Part of Turkey. J. Sci. Ind. Res. 2005, 64, 520-528.

34. Şensoy, A.; Şorman, A.A.; Tekeli, A.E.; Şorman, A.; Garen, D.C. Point-scale Energy and Mass Balance Snowpack Simulations in the Upper Karasu Basin, Turkey. Hydrol. Process. Int. J. 2006, 20, 899-922. [CrossRef]

35. Acar, R.; Şenocak, S.; Şengül, S. Snow Hydrology Studies in the Mountainous Eastern Part of Turkey. In Proceedings of the 2009 IEEE International Conference on Industrial Engineering and Engineering Management, Hong Kong, China, 8-11 December 2009; pp. 1578-1582.

36. Acar, R.; Şenocak, S.; Şengül, S.; Coşkun, T.; Balık Şanlı, F. Erzurum Kırkgöze Havzasında Kar Erimesine Etki Eden Meteorolojik Ölçümlerin Üç İstasyonda Karşılaştırılması. In Proceedings of the III. Ulusal Kar Kongresi, Erzurum, Turkey, 17-19 February 2009.

37. Şorman, A.A.; Uysal, G.; Şensoy, A. Probabilistic Snow Cover and Ensemble Streamflow Estimations in the Upper Euphrates Basin. J. Hydrol. Hydromech. 2019, 67, 82-92. [CrossRef]

38. Şengül, S. Dağlık Havzalarda Hidrolojik Çevrime Etki Eden Parametrelerin Coğrafi Bilgi Sistemleri ve HSPF Model Programıla İncelenmesi ve Kırkgöze Havzası Örneği. Ph.D. Thesis, Fen Bilimleri Enstitüsü, Atatürk Üniversitesi, Erzurum, Turkey, 2011. 
39. Şenocak, S. Kar Erimesi Akış Modelinin (SRM), Coğrafi Bilgi Sistemleri ve Uzaktan Algılama Teknikleri de Kullanılarak Dağlık Bölgelerde Uygulaması ve Erzurum Kırkgöze Havzası Örneği. Ph.D. Thesis, Fen Bilimleri Enstitüsü, Atatürk Üniversitesi, Erzurum, Turkey, 2011.

40. İspirli, M.N. HEC-HMS Model Programı Kullanılarak Dağlık Havzalarda Kar Erimesine Etki Eden Parametrelerin Belirlenmesi ve Kırkgöze Çipak Havzası'nın Hidrolojik Modellenmesi Determination of Parameters Affecting Snow Melting in Mountain Basins Using HEC-HMS Model Program and Hydrologic Modeling of Kırkgöze Çıpak Basin. Master's Thesis, Fen Bilimleri Enstitüsü, Atatürk Üniversitesi, Erzurum, Turkey, 2019.

41. Şengül, S. Küresel İklim Değişikliğinin Yağış ve Sıcaklık Üzerindeki Etkilerinin Kırkgöze Dağlık Havzasındaki Kar Kütlesi Üzerinde 2050 Yılı İçin Beklenen Etkilerinin HSPF Model Programı İle İncelenmesi. Avrupa Bilim Ve Teknol. Derg. 2019, 17, 611-636.

42. Akbulut, N.; Bayarı, S.; Akbulut, A.; Şahin, Y. Rivers of Turkey. In Rivers of Europe; Academic Press: London, UK, 2009 ; pp. 643-672.

43. Pekkan, E. Yukarı Fırat Havzasında Kar Erimesi Sürecininuydu Görüntüsü Analizlerive Izleyici Teknikleri Ile Incelenmesi. Ph.D. Thesis, Fen Bilimleri Enstitüsü, Hacettepe Üniversitesi, Ankara, Turkey, 2009.

44. Anonymous. Erzurum Projesi Mühendislik Jeolojisi Planlama Raporu; DSİ Genel Müdürlüğü; Jeoteknik Hizmetler ve Yeraltı Suları Dairesi Başkanlığı: Erzurum, Turkey, 1978; p. 48.

45. Gyawali, R.; Watkins, D.W. Continuous Hydrologic Modeling of Snow-Affected Watersheds in the Great Lakes Basin Using HEC-HMS. J. Hydrol. Eng. 2013, 18, 29-39. [CrossRef]

46. Chu, X.; Steinman, A. Event and Continuous Hydrologic Modeling with HEC-HMS. J. Irrig. Drain. Eng. 2009, 135, 119-124. [CrossRef]

47. Scharffenberg, B. Introduction to HEC-HMS. In Proceedings of the Watershed Modeling with HEC-HMS, California Water and Engineering Forum, Sacramento, CA, USA, 28 May 2008.

48. Khatri, H.B.; Jain, M.K.; Jain, S.K. Modelling of Streamflow in Snow Dominated Budhigandaki Catchment in Nepal. J. Earth Syst. Sci. 2018, 127, 100. [CrossRef]

49. Viessman, W.J.; Lewis, G.L. Introduction to Hydrology; Addison Wesley Longman: Boston, MA, USA, 1995.

50. USACE. Hydrologic Modeling System HEC-HMS Technical Reference Manual; U.S. Army Corps of Engineers: Hanover, NH, USA, 2000.

51. Fortin, J.-P.; Turcotte, R.; Massicotte, S.; Moussa, R.; Fitzback, J.; Villeneuve, J.-P. Distributed Watershed Model Compatible with Remote Sensing and GIS Data. I: Description of Model. J. Hydrol. Eng. 2001, 6, 91-99. [CrossRef]

52. Fleming, M.; Neary, V. Continuous Hydrologic Modeling Study with the Hydrologic Modeling System. J. Hydrol. Eng. 2004, 9 , 175-183. [CrossRef]

53. Khatami, S.; Khazaei, B. Benefits of GIS Application in Hydrological Modeling: A Brief Summary. Vatten Tidskr. För Vattenvård/J. Water Manag. Res. 2014, 70, 41-49.

54. Donigian, A.S.; Davis, H.H. User's Manual for Agricultural Runoff Management(ARM) Model; Environmental Protection Agency, Office of Research and Development, Environmental Research, Technology Development and Applications Branch: Washington, DC, USA, 1978.

55. Bennett, T.H. Development and Application of a Continuous Soil Moisture Accounting Algorithm for the HEC-HMS. Master's Thesis, Department of Civil and Environment Engineering, University of California, Davis, CA, USA, 1998.

56. Balk, B.; Elder, K. Combining Binary Decision Tree and Geostatistical Methods to Estimate Snow Distribution in a Mountain Watershed. Water Resour. Res. 2000, 36, 13-26. [CrossRef]

57. Erxleben, J.; Elder, K.; Davis, R. Comparison of Spatial Interpolation Methods for Estimating Snow Distribution in the Colorado Rocky Mountains. Hydrol. Process. 2002, 16, 3627-3649. [CrossRef]

58. Cosgrove, B.A.; Lohmann, D.; Mitchell, K.E.; Houser, P.R.; Wood, E.F.; Schaake, J.C.; Robock, A.; Marshall, C.; Sheffield, J.; Duan, Q. Real-time and Retrospective Forcing in the North American Land Data Assimilation System (NLDAS) Project. J. Geophys. Res. Atmos. 2003, 108, D22. [CrossRef]

59. Erickson, T.A.; Williams, M.W.; Winstral, A. Persistence of Topographic Controls on the Spatial Distribution of Snow in Rugged Mountain Terrain, Colorado, United States. Water Resour. Res. 2005, 41. [CrossRef]

60. Molotch, N.P.; Colee, M.T.; Bales, R.C.; Dozier, J. Estimating the Spatial Distribution of Snow Water Equivalent in an Alpine Basin Using Binary Regression Tree Models: The Impact of Digital Elevation Data and Independent Variable Selection. Hydrol. Process. Int. J. 2005, 19, 1459-1479. [CrossRef]

61. Liston, G.E.; Elder, K. A Meteorological Distribution System for High-Resolution Terrestrial Modeling (MicroMet). J. Hydrometeorol. 2006, 7, 217-234. [CrossRef]

62. Liston, G.E.; Elder, K. A Distributed Snow-Evolution Modeling System (SnowModel). J. Hydrometeorol. 2006, 7, 1259-1276. [CrossRef]

63. Winstral, A.; Marks, D. Long-term Snow Distribution Observations in a Mountain Catchment: Assessing Variability, Time Stability, and the Representativeness of an Index Site. Water Resour. Res. 2014, 50, 293-305. [CrossRef]

64. Fassnacht, S.R.; Brown, K.S.J.; Blumberg, E.J.; Moreno, J.L.; Covino, T.P.; Kappas, M.; Huang, Y.; Leone, V.; Kashipazha, A.H Distribution of Snow Depth Variability. Front. Earth Sci. 2018, 12, 683-692. [CrossRef]

65. Jeong, H.-G.; Ahn, J.-B.; Lee, J.; Shim, K.-M.; Jung, M.-P. Improvement of Daily Precipitation Estimations Using PRISM with Inverse-Distance Weighting. Theor. Appl. Climatol. 2020, 139, 923-934. [CrossRef] 
66. Acar, R.; Sengul, S. The Estimation of Average Areal Snowfall by Conventional Methods and the Percentage Weighting Polygon Method in the Northeast Anatolia Region, Turkey. Energy Educ. Sci. Technol. Part A-Energy Sci. Res. 2012, $29,11-22$.

67. Martinec, J.; Rango, A.; Roberts, R. Snowmelt Runoff Model User's Manual; USDA Jornada Experimental Range, New Mexico State University: Las Cruces, NM, USA, 2008.

68. USACE. Snow Hydrology; North Pacific Division; US Army Corps of Engineers: Portland, OR, USA, 1956.

69. Martinec, J. The Degree-Day Factor for Snowmelt Runoff Forecasting. IUGG Gen. Assem. Hels. IAHS Comm. Surf. Waters 1960, 51, 468-477.

70. Hock, R. Temperature Index Melt Modelling in Mountain Areas. J. Hydrol. 2003, 282, 104-115. [CrossRef]

71. Davtalab, R.; Mirchi, A.; Khatami, S.; Gyawali, R.; Massah, A.; Farajzadeh, M.; Madani, K. Improving Continuous Hydrologic Modeling of Data-Poor River Basins Using Hydrologic Engineering Center's Hydrologic Modeling System: Case Study of Karkheh River Basin. J. Hydrol. Eng. 2017, 22, 05017011. [CrossRef]

72. Momblanch, A.; Holman, I.P.; Jain, S.K. Current Practice and Recommendations for Modelling Global Change Impacts on Water Resource in the Himalayas. Water 2019, 11, 1303. [CrossRef]

73. Parajuli, A.; Nadeau, D.F.; Anctil, F.; Schilling, O.S.; Jutras, S. Does Data Availability Constrain Temperature-Index Snow Models? A Case Study in a Humid Boreal Forest. Water 2020, 12, 2284. [CrossRef]

74. Kumar, M.; Marks, D.; Dozier, J.; Reba, M.; Winstral, A. Evaluation of Distributed Hydrologic Impacts of Temperature-Index and Energy-Based Snow Models. Adv. Water Resour. 2013, 56, 77-89. [CrossRef]

75. He, Z.H.; Parajka, J.; Tian, F.Q.; Blöschl, G. Estimating Degree-Day Factors from MODIS for Snowmelt Runoff Modeling. Hydrol. Earth Syst. Sci. 2014, 18, 4773-4789. [CrossRef]

76. Bobál, P.; Podhorányi, M.; Mudroň, I.; Holubec, M. Mathematical Modelling of the Dynamics of Mountain Basin Snow Cover in Moravian-Silesian Beskydy for Operational Purposes. Water Resour. 2015, 42, 302-312. [CrossRef]

77. Bhuiyan, H.A.; McNairn, H.; Powers, J.; Merzouki, A. Application of HEC-HMS in a Cold Region Watershed and Use of RADARSAT-2 Soil Moisture in Initializing the Model. Hydrology 2017, 4, 9. [CrossRef]

78. USACE. SSARR Model, Streamflow Synthesis and Reservoir Regulation. In User Manual; US Army Corps of Engineers: Portland, OR, USA, 1991.

79. Bui, C. Application of HEC-HMS 3.4 in Estimating Streamflow of the Rio Grande under Impacts of Climate Change. Master's Thesis, The University of New Mexico, Albuquerque, NM, USA, 2011.

80. McEnroe, B.M. Guidelines for Continuous Simulation of Streamflow in Johnson County, Kansas, with HEC-HMS. Ph.D. Thesis, Department of Civil, Environmental and Architectural Engineering, University of Kansas, Lawrence, KS, USA, 2010.

81. Bicknell, B.R.; Imhoff, J.C.; Kittle, J.L., Jr.; Jobes, T.H.; Donigian, A.S., Jr. Hydrological Simulation Program-Fortran (HSPF). User's Manual for Release 12. US EPA National Exposure Research Laboratory, Athens, GA, in Cooperation with US Geological Survey; Water Resources Division: Reston, VA, USA, 2001.

82. Knoben, W.; Freer, J.; Woods, R. Technical Note: Inherent Benchmark or Not? Comparing Nash-Sutcliffe and Kling-Gupta Efficiency Scores. Hydrol. Earth Syst. Sci. Discuss. 2019, 23, 4323-4331. [CrossRef]

83. Krysanova, V.; Donnelly, C.; Gelfan, A.; Gerten, D.; Arheimer, B.; Hattermann, F.; Kundzewicz, Z.W. How the Performance of Hydrological Models Relates to Credibility of Projections under Climate Change. Hydrol. Sci. J. 2018, 63, 696-720. [CrossRef]

84. Demirel, M.C.; Mai, J.; Mendiguren, G.; Koch, J.; Samaniego, L.; Stisen, S. Combining Satellite Data and Appropriate Objective Functions for Improved Spatial Pattern Performance of a Distributed Hydrologic Model. Hydrol. Earth Syst. Sci. 2018, 22, 1299-1315. [CrossRef] 